
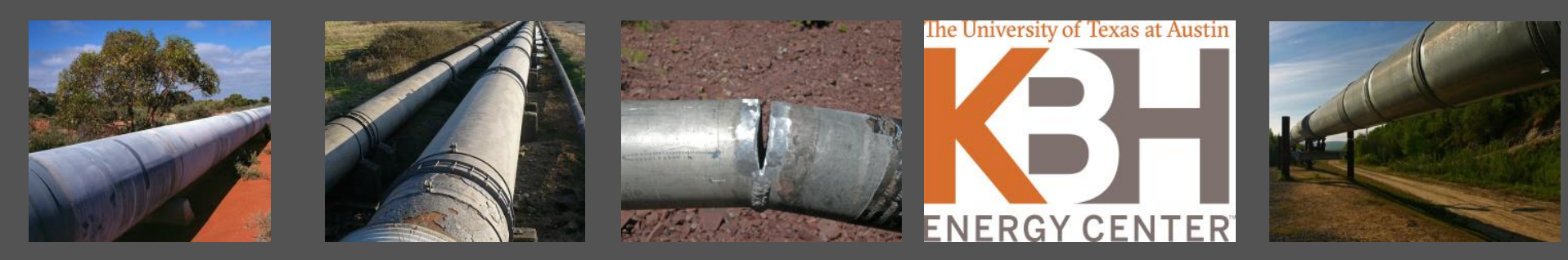

\title{
Safety First, Environment Last: Improving Regulation of Gas Pipeline Leaks
}

Romany Webb

September 2015

The University of Texas at Austin

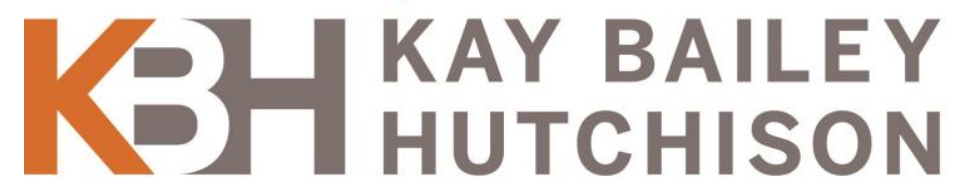

CENTER FOR ENERGY, LAW \& BUSINESS 



\section{Safety First, Environment Last: Improving Regulation of Gas Pipeline Leaks}

Research Paper No. 2015-02

September 2015

AUTHOR

Romany Webb

PRESENTED BY

Kay Bailey Hutchison Center for Energy, Law, and Business

University of Texas School of Law and McCombs School of Business

727 East Dean Keeton Street

Campus Mail Code: D1800

Austin, TX 78705

(512) 232-1408

UNDER THE DIRECTION OF

Melinda Taylor, Executive Director

The University of Texas at Austin

\section{7) KAY BAILEY 1) HUTCHISON}

CENTER FOR ENERGY, LAW \& BUSINESS

http://kbhenergycenter.utexas.edu/

(C) 2015 All rights reserved 



\section{ABOUT THE KBH ENERGY CENTER}

The Kay Bailey Hutchison Center for Energy, Law, and Business is an innovative interdisciplinary joint venture of the School of Law and the McCombs School of Business at The University of Texas at Austin. The mission of the KBH Energy Center is to provide the finest educational opportunities in the United States to students who wish to pursue careers in energy and to serve as a nexus for incisive, unbiased, and relevant research and analyses for policy makers, with a special emphasis on Latin America.

\section{ABOUT THE AUTHOR}

Romany Webb is a Post-Graduate Research Fellow at the KBH Energy Center. Romany's current research focuses on controlling greenhouse gas and other air emissions from energy production. Romany previously worked at the University of California, Berkeley, where she researched climate change policy. She has also practiced energy and water law in Sydney, Australia.

\section{ACKNOWLEDGEMENTS}

The author would like to thank Professor Thomas McGarity of the University of Texas School of Law, Professor David Spence of the McCombs School of Business and the University of Texas School of Law, and Professor Ian Duncan of the Bureau of Economic Geology at The University of Texas for their insightful comments on this paper. The author also thanks Melinda Taylor, Executive Director of the KBH Energy Center, for her helpful comments and advice. Additionally, the author is also grateful to Mauricio Pajón of the KBH Energy Center for his help in the production of this paper. Any errors are my own.

i | Safety First, Environment Last | September 2015 


\section{Table of Contents}

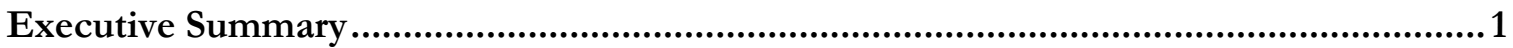

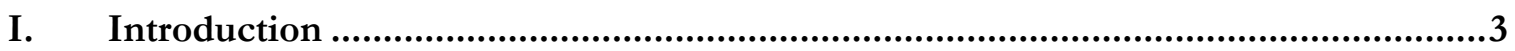

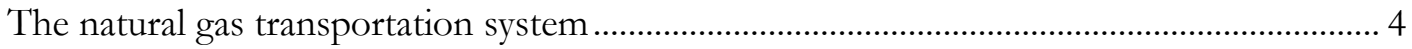

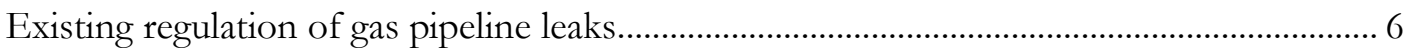

II. Detecting leaks in the pipeline system ............................................................. 8

Ensuring timely detection of pipeline system leaks ................................................................... 8

Minimum federal requirements for leak detection............................................................... 9

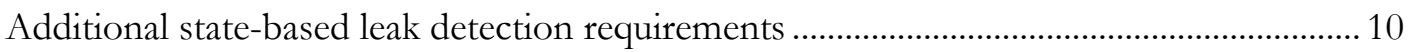

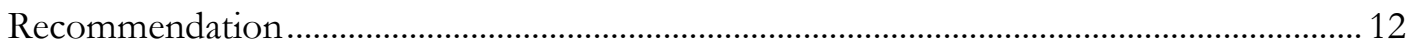

III. Repairing leaks in the pipeline system .............................................................. 13

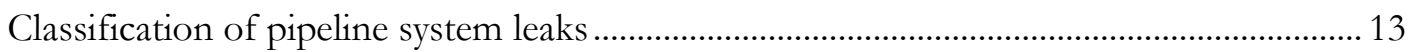

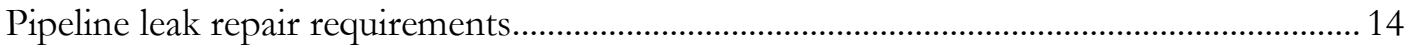

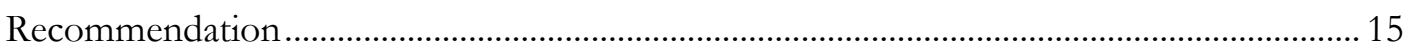

IV. Reporting pipeline system leaks ....................................................................... 17

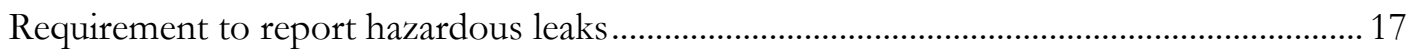

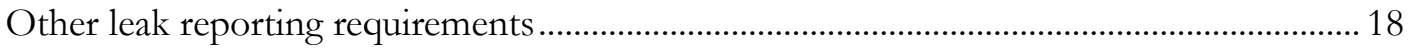

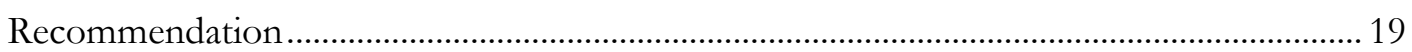

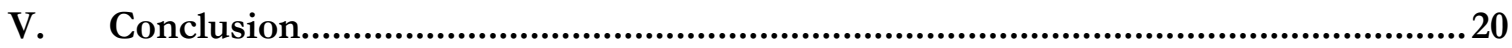

Appendix 1: State leak detection requirements .............................................................. 21

Appendix 2: State leak repair requirements.................................................................. 31

Appendix 3: State leak reporting requirements ............................................................. 42 


\section{Executive Summary}

Domestic natural gas production has increased significantly in recent years, with technological advances enabling the development of vast shale gas reserves previously considered inaccessible. Increased shale gas development has had many benefits, enhancing energy security, reducing consumer costs, and stimulating economic growth. However, it has also presented new challenges, particularly for environmental management.

Natural gas is often touted as a "clean" fossil fuel. Supporters emphasize that, compared to coal and oil, the combustion of natural gas produces fewer emissions of mercury and other air toxins that threaten public health. Moreover, natural gas combustion also results in fewer climatedamaging greenhouse gas emissions than coal or oil. These savings at the point of combustion may, however, be offset by greenhouse gas emissions further up the supply chain.

Methane - a short-lived but potent greenhouse gas - is released throughout the natural gas production process. Significant releases occur during the transportation of natural gas, including as a result of leaks from aging pipelines. Much of the pipeline system was installed over forty years ago and has degraded over time. Corrosion and graphitization have led to cracking of pipelines, resulting in gas leakage.

Recognizing this, the Department of Transportation's Pipeline and Hazardous Materials Safety Administration (PHMSA) has called on pipeline operators to accelerate the replacement of aging pipeline systems. While some progress has been made, it is likely to be several years before operators complete all replacement work. In the interim, significant amounts of natural gas may be lost as a result of leaks from aging pipelines. Moreover, even after those pipelines are replaced, leakage may continue due to cracks and/or other defects in newer systems.

Pipeline leaks present a major risk to public safety and cause significant environmental damage. Seeking to minimize these adverse impacts, the PHMSA has adopted regulations governing leak detection and repair under the Natural Gas Pipeline Safety Act of 1968 (49 U.S.C. \ 1671 et seq.). The Act requires adoption of regulations that are "designed to meet the need for gas pipeline safety . . . and protecting the environment." The current regulations do not, however, achieve these dual purposes. Rather, the regulations focus primarily on minimizing risks to public safety and do little to advance environmental outcomes.

The PHMSA now has an opportunity to enhance regulation of gas leaks so as to provide for greater environmental protection in accordance with the Natural Gas Pipeline Safety Act (49 U.S.C. $\int 1671$ et seq.). In January 2015, as part of its efforts to curb methane emissions from natural gas production, the Obama Administration announced plans to update the regulations.

1 | Safety First, Environment Last | September 2015 
To inform the update process, this White Paper analyzes the current regulations with respect to leak detection, repair, and reporting. It recommends changes to those regulations designed to encourage improved leak management. These include:

- Pipelines should be regularly inspected for leaks. Federal regulations currently require pipeline operators to conduct system inspections to detect leaks. Frequent inspections must be conducted, one or more times per year, in business districts and other populated areas. In more remote locations, however, several years may elapse between inspections. Consequently, in those locations, leaks may go undetected for extended periods. To ensure prompt leak detection, all pipelines should be inspected for leaks at least annually. More frequent inspections may be required for pipelines at high risk of gas leakage.

- Leaks detected on the pipeline system should be repaired promptly. Pipeline operators classify leaks based on the risk they pose to public safety. The most serious leaks, classified as hazardous to the public, must be repaired promptly. Leaks classified as non-hazardous can, however, generally be left unrepaired. The classification of a leak is based largely on its proximity to buildings, rather than its size. Thus, leaks in isolated areas may be classified as non-hazardous and left unrepaired, even if they release substantial amounts of natural gas. Going forward, pipeline operators should be required to repair all large leaks (regardless of location) immediately and smaller leaks within one year of detection. It is likely to be simplest to include this requirement in the federal regulations; however, the requirement could also be incorporated into state pipeline safety rules.

- Gas losses due to pipeline leaks should be measured and reported. Pipeline operators are required to report, to the PHMSA, the number of leaks repaired each year. Notably however, operators generally do not report the number of unrepaired leaks. Moreover, operators do not quantify the volume of gas lost through such leaks. This makes it difficult for regulators and others to assess the extent of gas leakage. To facilitate such assessment, operators should be required to accurately measure the volume of gas lost through leaks. The results of these measurements should be reported to the PHMSA. The PHMSA should make the reported measurements available to other interested parties.

2 | Safety First, Environment Last | September 2015 


\section{Introduction}

Over the last decade, domestic natural gas production has increased by approximately forty-two percent, exceeding twenty-five trillion cubic feet for the first time in $2014 .{ }^{1}$ This increase has been driven by recent technological advances - including the combination of horizontal drilling with hydraulic fracturing - enabling the extraction of previously inaccessible shale gas reserves. In 2000, shale gas represented less than two percent of domestic natural gas supplies. ${ }^{2}$ By 2013, it was forty-seven percent and rising. ${ }^{3}$

This so-called "shale gas revolution" presents unique environmental challenges. On the plus side, increased shale gas development has opened up a vast new source of relatively clean energy. Substituting natural gas for coal or oil in electricity generation can help to lower emissions of mercury and other air toxins that threaten public health. ${ }^{4}$ Moreover, switching to natural gasfired generation can also reduce climate-damaging greenhouse gas emissions. ${ }^{5}$ The U.S. Environmental Protection Agency (EPA) estimates that the combustion of natural gas emits thirty to fifty percent less carbon dioxide and sixty to seventy percent less nitrogen oxides than oil and coal respectively. ${ }^{6}$ These savings may, however, be offset by greenhouse gas emissions during natural gas production.

Natural gas is comprised principally of methane - a potent but short-lived greenhouse gas which is released throughout the production process due to intentional venting and accidental leaks. As methane has a global warming potential eighty-four times that of carbon dioxide over a twenty year timescale, these leaks can make a significant contribution to climate change, offsetting the benefits of increased natural gas use. ${ }^{7}$ Recent research suggests that, where leaks exceed two to three percent of natural gas production, electricity generation using gas may have the same climate impacts as coal-fired generation. ${ }^{8}$

The EPA estimates that natural gas systems ${ }^{9}$ were the largest industrial emitter of methane in the U.S. in 2013, accounting for nearly one-quarter of national emissions. ${ }^{10}$ Recognizing this, in the 2013 Climate Action Plan, President Obama pledged to reduce gas system emissions. ${ }^{11}$ Fulfilling this pledge, in January 2015, the Obama Administration directed the EPA to establish rules limiting emissions from gas production sites and certain processing and transportation facilities. ${ }^{12}$ The EPA unveiled draft rules, applying to new and modified facilities, in August 2015. Building on these rules, other agencies are also expected to announce new measures to curb emissions. ${ }^{13}$ The Department of Transportation, for example, is considering imposing stricter controls on gas pipeline leaks. ${ }^{14}$

3 | Safety First, Environment Last | September 2015 


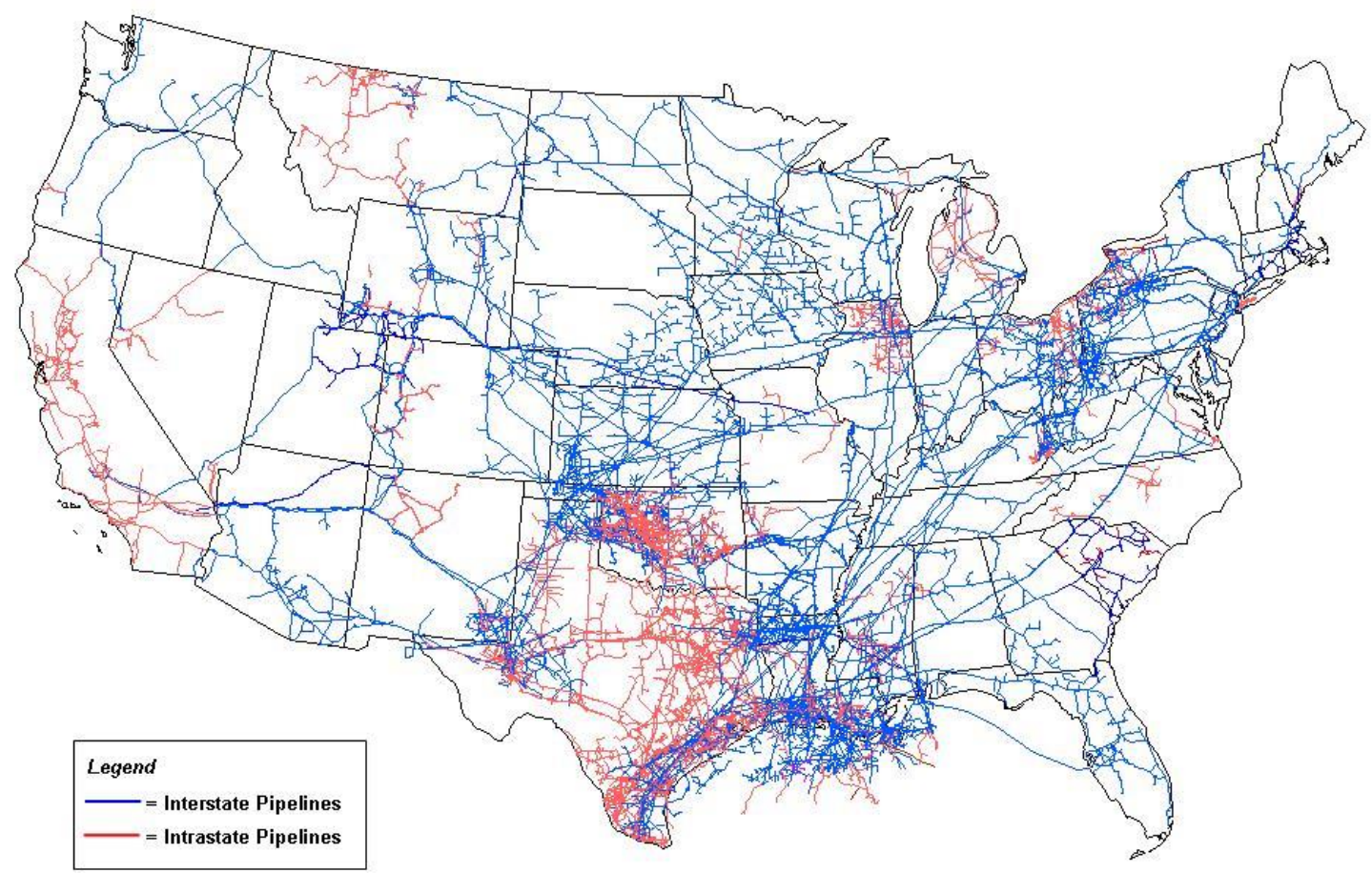

FIGURE 1: U.S. NATURAL GAS PIPELINE NETWORK

SOURCE: U.S. ENERGY INFORMATION ADMINISTRATION (2009). TO SEE A HIGH-RESOLUTION, LARGEFORMAT VERSION OF THE MAP, VISIT HTTP://WWW.EIA.GOV/PUB/OIL GAS/NATURAL GAS/ANALYSIS PUBLICATIONS/NGPIPELINE/NGPIPELINES MAP.HTML

\section{The natural gas transportation system}

The EPA estimates that natural gas transportation and storage accounted for nearly fourteen percent of methane emissions in the U.S. in 2013. ${ }^{15}$ Methane is emitted throughout the gas transportation process, largely due to leakage from cracked or broken pipelines.

Approximately 2.5 million miles of pipelines are used in the transportation of natural gas. The pipeline system is typically divided into three parts as follows:

- the gathering system, which comprises small diameter, low pressure pipelines used to transport natural gas from field production areas to centralized processing facilities;

- the transmission system, which comprises large, high capacity pipelines used to move natural gas from gathering, processing, and storage facilities to local utilities (known as local distribution companies (LDCs)) and large volume consumers (e.g., power plants and industrial facilities); and

- the distribution system, which comprises smaller pipelines used to deliver natural gas to residential, commercial, and industrial consumers. ${ }^{16}$ Distribution mains convey gas from 
the city gate (i.e., the point at which gas is transferred from a transmission pipeline to the LDC) to service lines for delivery to consumers. ${ }^{17}$

Much of the nation's pipeline infrastructure is forty to fifty years old. Approximately thirty percent of gas distribution mains were installed prior to 1970.18 The figure is even higher for gas transmission lines, with approximately fifty-seven percent installed prior to $1970 .{ }^{19}$ Indeed, over thirty-three percent of transmission lines are more than fifty years old, with 34,234 miles of pipe installed prior to 1950 and a further 71,440 installed between 1950 and 1959.20

These aging transmission and distribution pipelines often experience high rates of gas leakage. Many older pipes, particularly distribution mains and service lines, are made of cast or wrought iron which is prone to graphitization. ${ }^{21}$ During this process, the iron degrades to softer elements, leading to cracks. ${ }^{22}$ Cracking may also occur due to corrosion of old copper and bare steel pipelines, particularly those installed prior to the 1960s, when pipes were typically manufactured without a protective outer-coating. ${ }^{23}$ Similarly, plastic pipes manufactured and installed from the late 1960 s to the early 1980 s are also prone to cracking. ${ }^{24}$

Recognizing the potential for gas leakage, in March 2012, the Department of Transportation's Pipeline Safety and Hazardous Materials Administration (PHMSA) issued an advisory bulletin urging pipeline operators to accelerate the replacement of aging pipes. ${ }^{25}$ To encourage pipe replacement, the Federal Energy Regulatory Commission ${ }^{26}$ recently adopted new rules making it easier for operators of interstate pipelines to recover capital expenditures on system modernization. ${ }^{27}$ Similar rules, applying to intrastate pipelines, have been adopted in twentyseven states and the District of Columbia. ${ }^{28}$

Even with these policies, replacement of aging pipeline systems could take many years. ${ }^{29}$ In the interim, the systems will likely experience increasing rates of gas leakage. Moreover, leaks may also occur on newly installed pipelines due to earth movement, operator error, mechanical failure, equipment defects, and third party damage.

Pipeline leaks may be repaired in various ways, depending on the characteristics of the pipe and the cause of the leak, among other factors. Large leaks, caused by corrosion or other major failures, are often repaired by excavating the pipeline and replacing the corroded section or covering it with a sleeve..$^{30}$ This is not, however, always required. Many leaks can be repaired internally by, for example, using cables to insert a liner into the pipe or applying a sealant onto the interior surface thereof using devices known as pigs. ${ }^{31}$ While these methods are typically inexpensive, the sheer number of pipeline leaks may make instituting a comprehensive repair program costly. Recent studies have found that, in some areas, one pipeline leak occurs every

5 | Safety First, Environment Last | September 2015 
mile. ${ }^{32}$ The recent decline in natural gas prices, triggered by expanding shale production, has likely reduced incentives for pipeline operators to voluntarily repair leaks. ${ }^{33}$

Leaking gas poses a serious risk to public safety, with pipeline leaks blamed for deadly explosions in Manhattan, New York, in 2014, ${ }^{34}$ San Bruno, California, in 2010, 35 Bergenfield, New Jersey, in 2005, ${ }^{36}$ and Allentown, Pennsylvania, in 1994. ${ }^{37}$ Moreover, gas leaks can also have devastating consequences for the environment, accelerating global climate change. It is, therefore, vital that pipeline operators adopt effective systems for finding and fixing leaks. Unfortunately however, existing regulations do little to encourage operators to aggressively find and fix leaks.

\section{Existing regulation of gas pipeline leaks}

Regulatory authority over natural gas pipelines is shared between the federal government and the states. At the federal level, the Department of Transportation regulates pipelines with a view to ensuring public safety. The Natural Gas Pipeline Safety Act of 1968 (49 C.F.R. \1671 et seq.) directed the Secretary of Transportation to establish minimum safety standards for gas pipelines. Fulfilling this requirement, regulations governing pipe design, construction, operation, and maintenance have been adopted by the PHMSA.

The PHMSA regulations outline minimum requirements applicable to pipelines in every state. They are designed to address key pipeline safety issues arising nationwide. As individual states may face their own pipeline safety challenges, each state has the option of implementing additional or more stringent rules. ${ }^{38}$ The overwhelming majority of states have exercised this option and adopted their own pipeline safety rules. ${ }^{39}$ These state-based rules apply (in addition to the federal regulations) to pipelines located entirely within the boundaries of the relevant state (i.e., intrastate pipelines). ${ }^{40}$ Other (interstate) pipelines are subject only to the federal safety regulations.

Both the federal and state pipeline safety regulations include provisions designed to reduce gas leakage. The focus of the regulations is on preventing and controlling leaks that pose a hazard to the public. The regulations do little to address other leaks which, while not hazardous to the public, may damage the environment. This is arguably contrary to the Natural Gas Pipeline Safety Act (49 C.F.R. $\int 1671$ et seq.) which requires the regulations to be "designed to meet the need for gas pipeline safety... and protecting the environment." 41

The PHMSA has an opportunity to revise its regulations to provide for greater environmental protection in accordance with the Natural Gas Pipeline Safety Act (49 C.F.R. \ 1671 et seq.). In January 2015, as part of its efforts to reduce methane emissions from the natural gas industry, the Obama Administration announced plans to update the pipeline safety regulations. ${ }^{42}$ To

6 | Safety First, Environment Last | September 2015 
Kay Bailey Hutchison Center for Energy, Law, and Business

inform the update process, this White Paper identifies key shortcomings in the regulatory regime governing pipeline leaks. It recommends improvements to that regime designed to encourage improved leak management. 


\section{Detecting leaks in the pipeline system}

Early detection of pipeline system leaks is vital to assure public safety and minimize environmental damage. Recognizing this, federal and state regulators require pipeline operators to conduct periodic system inspections aimed at detecting leaks. Notably however, while operators are required to conduct frequent inspections in populated areas, the regulations often allow long intervals between inspections in remote locations. Consequently, in those locations, pipeline leaks may go undetected for months or even years. During that time, significant amounts of natural gas may be released, increasing atmospheric methane levels and thereby accelerating global climate change.

\section{Ensuring timely detection of pipeline system leaks}

Various methods can be used to detect leaks in the pipeline system. Many pipeline operators rely, in the first instance, on sensory inspections to detect system leaks. For example, the system may be visually inspected by walking, driving, or flying along the pipeline route to look for indications of gas leakage, such as changes in vegetation, fungus-like growth, or heavy insect activity. ${ }^{43}$ Additionally, the inspector may also listen for the hissing sound made by gas leaks. ${ }^{44}$ Specialized acoustic emissions sensors may also be used to detect leaks based on changes in the background noise pattern. 45

These sensory monitoring techniques are unlikely, by themselves, to detect all pipeline system leaks. Small leaks, for example, often do not affect vegetative growth and may therefore be difficult to detect visually. ${ }^{46}$ Moreover, as those leaks produce little noise, they can be difficult to detect through acoustic methods. ${ }^{47}$ For this reason, pipeline operators also employ other, more sophisticated techniques for detecting leaks. Operators may detect leaks using sampling instruments, such as flame ionization detectors and combustible gas indicators, which measure the concentration of gas in the air around a pipeline. 48 Thermal imaging and similar equipment may be used to detect leaks based on differences in temperature in the pipeline area. ${ }^{49}$ Other optical devices work by illuminating the area above the pipeline and measuring the extent to which the light is absorbed or scattered to infer the presence of leaks. ${ }^{50}$

The various leak detection systems each have advantages and disadvantages. The use of sampling instruments, for example, has the advantage of enabling detection of small leaks. However, it can be time-consuming as gas measurements must be collected along the length of the pipeline. Thermal imaging can often be performed more quickly, as imagers can be installed on moving vehicles and used to detect leaks along several miles per day. It does however, tend to be less accurate than gas sampling.

8 | Safety First, Environment Last | September 2015 
Regardless of the method(s) used, any leak detection program must include regular monitoring of the pipeline system. In the absence of regular monitoring, leaks may persist for extended periods. Where this occurs, gas may build up over time, increasing the risk of a major pipeline rupture. Even if such a rupture does not occur, the rate of gas leakage may increase with time if a leak is not detected and repaired. ${ }^{11}$ Frequent system monitoring helps to ensure that leaks are detected quickly, enabling repair work to be performed before significant gas leakage occurs.

\section{Minimum federal requirements for leak detection}

The PHMSA has established minimum requirements for leak detection on all pipeline systems. ${ }^{52}$ PHMSA regulations require pipeline operators to detect system leaks using two key methods. Firstly, each operator must have a patrol program under which its system is visually inspected for signs of gas leakage. ${ }^{53}$ Additionally, the operator must also conduct leak surveys using flame ionization devices, combustible gas indicators, or other equipment to detect gas in the air. ${ }^{54}$

The frequency at which patrols and surveys must be conducted depends on the nature of the pipeline system and the risks it poses to public safety. Generally, due to the large volume of gas they carry, transmission pipelines are considered to present the greatest public safety risk. Those pipelines must, therefore, be inspected more frequently than distribution pipelines. Pipelines in built-up areas typically require more frequent inspection than those in isolated locations.

\section{TABLE 1: FEDERAL PIPELINE INSPECTION REQUIREMENTS}

\begin{tabular}{|c|c|c|}
\hline Location of the pipeline & Frequency of patrols & Frequency of surveys \\
\hline \multicolumn{3}{|l|}{ Transmission pipelines } \\
\hline $\begin{array}{l}\text { In Class } 1 \text { locations, where less than } \\
10 \text { buildings intended for human } \\
\text { occupancy are situated within } 220 \\
\text { yards on either side of the pipeline }\end{array}$ & \multirow{2}{*}{$\begin{array}{l}\text { Twice per year (at } 7.5 \text { month } \\
\text { intervals), at highway and } \\
\text { railroad crossings } \\
\text { Once per year (at } 15 \text { month } \\
\text { intervals), in all other areas }\end{array}$} & \multirow[t]{2}{*}{$\begin{array}{l}\text { Once per year (at } 15 \text { month } \\
\text { intervals) } 55\end{array}$} \\
\hline $\begin{array}{l}\text { In Class } 2 \text { locations, where more } \\
\text { than } 10 \text { but less than } 46 \text { buildings } \\
\text { intended for human occupancy are } \\
\text { situated within } 220 \text { yards on either } \\
\text { side of the pipeline }\end{array}$ & & \\
\hline $\begin{array}{l}\text { In Class } 3 \text { locations, where } 46 \text { or } \\
\text { more buildings intended for human } \\
\text { occupancy are situated within } 220 \\
\text { yards on either side of the pipeline } \\
\text { or a building or small outside area } 56 \\
\text { occupied by at least } 20 \text { persons } 5 \\
\text { days per week for } 10 \text { weeks per year } \\
\text { is situated within } 100 \text { yards }\end{array}$ & $\begin{array}{l}4 \text { times per year (at } 4.5 \\
\text { month intervals), at highway } \\
\text { and railroad crossings } \\
\text { Twice per year (at } 7.5 \text { month } \\
\text { intervals), in all other areas }\end{array}$ & $\begin{array}{l}\text { Once per year (at } 15 \text { month } \\
\text { intervals) for all other } \\
\text { pipelines }^{57}\end{array}$ \\
\hline
\end{tabular}

9 | Safety First, Environment Last | September 2015 


\begin{tabular}{|c|c|c|}
\hline Location of the pipeline & Frequency of patrols & Frequency of surveys \\
\hline $\begin{array}{l}\text { In Class } 4 \text { locations, where buildings } \\
\text { with four or more stories are } \\
\text { prevalent within } 220 \text { yards on either } \\
\text { side of the pipeline }\end{array}$ & $\begin{array}{l}4 \text { times per year (at } 4.5 \\
\text { month intervals) }\end{array}$ & $\begin{array}{l}\text { Once per year (at } 15 \text { month } \\
\text { intervals) }\end{array}$ \\
\hline \multicolumn{3}{|l|}{ Distribution pipelines } \\
\hline $\begin{array}{l}\text { Within business districts, being areas } \\
\text { used to buy and sell commodities } \\
\text { and service and for related } \\
\text { transactions }\end{array}$ & $\begin{array}{l}4 \text { times per year (at } 4.5 \\
\text { month intervals) on } \\
\text { distribution mains, } 60 \text { where } \\
\text { movement or loading could } \\
\text { cause leakage }\end{array}$ & $\begin{array}{l}\text { Once per year (at } 15 \text { month } \\
\text { intervals) }^{61}\end{array}$ \\
\hline Outside of business districts & $\begin{array}{l}\text { Twice per year (at } 7.5 \text { month } \\
\text { intervals) on distribution } \\
\text { mains, }{ }^{62} \text { where movement or } \\
\text { loading could cause leakage }\end{array}$ & $\begin{array}{l}\text { Once every } 3 \text { years (at } 39 \\
\text { month intervals), for certain } \\
\text { cathodically unprotected } \\
\text { pipelines } \\
\text { Once every } 5 \text { years (at } 63 \\
\text { month intervals), for all } \\
\text { other pipelines }^{63}\end{array}$ \\
\hline
\end{tabular}

As indicated in Table 1 above, operators of transmission pipelines must conduct regular patrols, during which the pipeline system is visually inspected for signs of gas leakage. Such inspections must be completed one to four time(s) per year, depending on the location of the pipeline. Notably however, comprehensive surveys using leak detection equipment need only be completed every fifteen months. Thus, since visual inspections may not identify all instances of gas leakage, transmission pipeline leaks may not be detected for a year or more (if at all). Given the large volume of gas carried by transmission pipelines, such long-term leaks could pose a serious threat to public safety and have devastating consequences for the environment.

Compared to transmission pipelines, leakage surveys of most distribution systems occur less frequently. Some distribution pipelines, located within business districts, must be surveyed for leaks each year. With limited exceptions, however, distribution pipelines outside of business districts need only be surveyed for leaks once every five years. Therefore, and since only certain distribution mains are regularly patrolled, leaks may not be detected for several months or years (if at all).

\section{Additional state-based leak detection requirements}

Recognizing the shortcomings in the existing federal regulations, a number of states have adopted their own rules with respect to pipeline leak detection. These state rules apply, in addition to the federal regulations, to operators of intrastate pipelines within the relevant state. Other interstate pipelines are subject only to the federal regulations. 
The leak detection requirements in each state are summarized in Appendix 1 to this White Paper. As indicated there, eighteen states and the District of Columbia have adopted rules requiring pipeline operators to conduct more frequent system inspections to detect leaks. ${ }^{64}$ Nevertheless, in most cases, the state-based rules still do not ensure timely detection of all leaks. Consistent with the federal regulations, most states prioritize leak detection in built-up areas. While the states generally require pipeline operators to conduct frequent system inspections in those areas, they often allow long intervals between inspections in remote locations. As a result, in those locations, pipeline leaks may go undetected for months or years.

Seeking to ensure timely detection of all leaks, some states require pipeline operators to conduct frequent inspections in both populated and remote locations. By way of example, in Arizona, all transmission pipelines (regardless of location) must be surveyed for leaks semiannually. ${ }^{65}$ Arizona requires annual leakage surveys of all master meter systems used to distribute gas (regardless of location). ${ }^{66}$ Similarly, annual leakage surveys of all distribution systems (regardless of location) are also required in Maine. ${ }^{67}$ This ensures that all leaks, in both populated and remote areas, are detected quickly.

Eight states require more frequent inspection of pipelines at high risk of leakage. Washington is a good example. There, most pipelines must be surveyed for leaks once each year. ${ }^{68} \mathrm{~A}$ second leak survey must be conducted each year on pipelines manufactured using cast iron, wrought iron, copper, and non-cathodically protected steel. ${ }^{69}$ Similar requirements have also been adopted in other states, including:

- Florida, which requires bare metallic, galvanized steel, and coated tubing pipelines located outside of business districts to be surveyed every three years (compared to every five years for other pipelines located outside business districts); $;^{70}$

- Kansas, which requires cathodically unprotected steel pipelines located outside of business districts to be surveyed once per year (compared to once every five years for protected steel pipelines located outside business districts); $;^{71}$

- Maryland, which requires cast iron, ductile iron, and cathodically unprotected steel pipelines located outside of business districts to be surveyed for leaks every three years (compared to every five years for other pipelines located outside business districts); $;^{72}$ and

- Missouri, which requires unprotected steel pipelines located outside of business districts to be surveyed for leaks once each calendar year (compared to once every three years for other pipelines located outside business districts). ${ }^{73}$

11 | Safety First, Environment Last | September 2015 
These risk-based programs ensure frequent inspection of those pipelines most likely to experience gas leakage, increasing the efficacy of the leak detection program. However, because only some pipelines are regularly inspected, the costs to pipeline operators are minimized.

\section{Recommendation}

Building on its existing regulations, the PHMSA should require pipeline operators to conduct more frequent system inspections to detect leaks. As noted above, PHMSA's existing regulations only require operators to conduct frequent leak surveys in populated areas. In more remote locations, several years may elapse between surveys, with the consequence that leaks often go undetected for extended periods. To address this problem, a number of states have adopted their own rules requiring more frequent surveys to detect leaks. In Arizona and Maine, for example, annual leak surveys are required.

Consistent with the states' approach, the PHMSA should require all transmission and distribution pipelines to be surveyed for leaks annually, regardless of their location. The PHMSA should also consider requiring more frequent surveys of some high-risk systems, including those manufactured from cast iron, wrought iron, copper, and bare steel and some vintages of plastic pipe that are prone to leakage. This approach has been successfully adopted in a number of states, including Washington, whose regulations could serve as a model for the PHMSA. 


\section{Repairing leaks in the pipeline system}

Due to the large volume of gas transported via pipeline, a single leak can have devastating consequences, particularly if not repaired quickly. Where a leak is left unrepaired, gas may buildup over time and, if ignited, trigger an explosion. The PHMSA estimates that, across the gas transmission system, there were 1,265 major pipeline incidents resulting in death, personal injury, or serious property damage between 1995 and $20144^{74}$ Over the same period, there were an additional 1,489 major incidents on the gas distribution system. ${ }^{75}$ There were also many other smaller leaks which did not threaten persons or property. While often considered trivial, such leaks can have major environmental impacts, increasing atmospheric methane levels and thereby accelerating global climate change. Despite this, however, pipeline operators often leave these so-called trivial leaks unrepaired for several months or even years.

\section{Classification of pipeline system leaks}

In determining whether to repair a leak, pipeline operators consider the extent of potential hazard resulting therefrom. Regulations issued by the PHMSA require operators to prioritize repair of hazardous leaks. ${ }^{76}$ To facilitate the identification of such leaks, most operators have adopted a uniform set of leak classifications, based on standards developed by the Gas Piping Technology Committee. ${ }^{77}$ The standards establish three leak classes or grades as follows:

- Grade 1 leaks are those that represent an existing or probable hazard to persons or property;

- Grade 2 leaks are those that are recognized as being non-hazardous at the time of detection, but justify scheduled repair based on probable future hazard; and

- Grade 3 leaks are those that are non-hazardous at the time of detection and can reasonably be expected to remain non-hazardous. ${ }^{78}$

This three-tiered classification system has been endorsed by the PHMSA. ${ }^{79}$ Sixteen states have adopted regulations requiring pipeline operators to classify leaks in accordance with this system. ${ }^{80}$ An additional two states require operators to use a four-tiered classification system, which sub-divides Grade 2 leaks into two categories, based on their severity. ${ }^{81}$

When classifying leaks, pipeline operators must assess the extent to which gas leakage poses a hazard to persons or property. This assessment is based primarily on the location of the leak. ${ }^{82}$ Leaks in populated areas, close to homes and/or other inhabited buildings, are typically classified as hazardous. Notably however, leaks in remote locations are often classified as non-hazardous, even if they release substantial amounts of natural gas. Indeed, regulations in a number of states

13 | Safety First, Environment Last | September 2015 
expressly provide that a large leak which can be seen, heard, or felt should only be classified as hazardous if it is in a location that may endanger the public. ${ }^{83}$

By focusing on the location of leaks rather than their size, the leak classification system fails to account for the environmental impacts of gas leakage. Large leaks which have a major impact on the environment may be classified as non-hazardous, provided that they are situated in remote locations, away from persons or property. This classification trivializes such leaks, encouraging pipeline operators and others to view them as unimportant. That view has important consequences for leak repair.

\section{Pipeline leak repair requirements}

Regulations issued by the PHMSA require pipeline operators to ensure the prompt repair of leaks posing an immediate hazard to persons or property (i.e., Grade 1 leaks). ${ }^{84}$ The regulations do not, however, require pipeline operators to repair other, non-hazardous leaks. Therefore, in states that have not adopted their own pipeline safety regulations, operators enjoy significant discretion to choose whether and when to repair such leaks.

Appendix 2 to this White Paper outlines the regulations governing leak repair in each state. As indicated there, the majority of states do not require pipeline operators to repair non-hazardous leaks. Rather, in most states, operators are merely required to periodically reevaluate such leaks to assess whether they have become hazardous. Any leak that becomes hazardous must be repaired promptly. However, leaks that remain non-hazardous can be, and often are, left unrepaired. This not only wastes a valuable resource, but also threatens the environment, accelerating global climate change.

Recognizing this, several states have adopted their own leak repair standards. Building on the federal regulations mandating prompt repair of leaks posing an immediate hazard to persons or property, fifteen states have standards establishing maximum timeframes for the repair of other, non-hazardous leaks. ${ }^{85}$ These standards may have contributed to a decline in gas leakage. Data collected by the Energy Information Administration indicates that, in 2013, approximately 0.14 percent of all gas transported via pipeline was lost through leaks. ${ }^{86}$ Leakage was highest in states without repair timeframes, averaging 0.23 percent. ${ }^{87}$ In contrast, the average leak rate in states with repair timeframes was just 0.12 percent. 88 While it is difficult to tie this to any specific policy, it seems likely that adopting repair timeframes will lead to a decline in leakage rates.

The impact of any state policy will depend on the time allowed for leak repair. As noted above, fifteen states have established maximum timeframes for the repair of leaks that do not pose a hazard at the time of detection, but may become hazardous in the future (Grade 2 leaks). Some

14 | Safety First, Environment Last | September 2015 
of the toughest requirements are in Florida, which requires pipeline operators to repair all Grade 2 leaks within thirty days of detection. ${ }^{89}$ Similarly, in Missouri, pipeline operators must repair Grade 2 leaks within fifteen to forty-five days (depending on location)..$^{90}$ This is not, however, the norm. The majority of states allow pipeline operators significantly more time to complete repairs. Indeed, in nine states, operators may make repairs six months or more after a leak is detected. ${ }^{91}$ In five of these states, repairs need not occur for twelve to fifteen months. ${ }^{92}$

Like Grade 2 leaks, Grade 3 leaks are often left unrepaired for several months or even years. Just four states - Kansas, Maine, Missouri, and Texas - have established mandatory timeframes for the repair of all Grade 3 leaks. A further two states - Arizona and Florida - have timeframes for the repair of some Grade 3 leaks. The timeframes vary significantly between states.

TABLE 2: STATE RULES FOR REPAIR OF GRADE 3 LEAKS

\begin{tabular}{|l|l|}
\hline State & Maximum time for repair of Grade 3 leaks \\
\hline Arizona & 12 months (for underground leaks from transmission pipelines only) \\
\hline Florida & 90 days (for above-ground leaks only) \\
\hline Kansas & 30 months $^{95}$ \\
\hline Maine & 24 months $^{96}$ \\
\hline Missouri & 60 months $^{97}$ \\
\hline Texas & 36 months $^{98}$ \\
\hline
\end{tabular}

As indicated above, most states do not require pipeline operators to repair Grade 3 leaks. Operators can often avoid repairing other leaks, or extend the time for repair, by venting the leaked gas to the atmosphere. ${ }^{99}$ This approach is commonly used to address hazardous Grade 1 leaks. Where such a leak is detected, the pipeline operator may vent the leaking gas to reduce pressure and minimize the risk of a pipeline explosion. Once this occurs, the leak can then be reclassified into Grade 2 or 3, giving the pipeline operator more time to complete repairs.

While venting may reduce the risk of a pipeline explosion, it can have major impacts on the environment. Recognizing this, some states have restricted the downgrading of leaks through venting. In Maine, for example, pipeline operators may not downgrade a leak unless it has been repaired. ${ }^{100}$ Similarly, in Ohio, operators wishing to downgrade a leak must perform physical action to the pipeline. ${ }^{101}$ For this purpose, venting is not considered a physical action. ${ }^{102}$

\section{Recommendation}

Policy makers should adopt more comprehensive rules for the classification and repair of pipeline leaks. As discussed above, PHMSA's regulations require prompt repair of leaks classified 
as hazardous, but establish no repair requirements for other non-hazardous leaks. Under the regulations, the classification of a leak as hazardous or non-hazardous is based largely on its proximity to buildings, rather than its size. Leaks in isolated areas may, therefore, be classified as non-hazardous and left unrepaired, even if they release substantial amounts of gas.

Recognizing this shortcoming in the federal regulations, a few states have adopted their own standards, requiring the repair of non-hazardous leaks. In most states, however, pipeline operators enjoy significant discretion to decide if and when to repair such leaks. To remedy this problem, additional rules governing pipeline leak repair should be adopted. These rules should require pipeline operators to consider the extent of gas loss when determining whether to repair leaks. All large leaks, regardless of location, should be treated as hazardous and repaired immediately upon detection. Other non-hazardous leaks should be repaired within one year after detection. While it may be simplest to include these requirements in the federal pipeline safety regulations, they could also be incorporated into the state-based rules. 


\section{Reporting pipeline system leaks}

As natural gas is up to ninety percent methane - a short-lived but potent greenhouse gas pipeline system leaks can make a significant contribution to climate change. It is, however, often difficult to assess the extent of that contribution due to the lack of accurate data on gas leakage. While existing regulations require pipeline operators to report significant gas leaks, posing a hazard to public safety, reporting is generally not required for smaller leaks.

\section{Requirement to report hazardous leaks}

Federal pipeline safety regulations, issued by the PHMSA, aim to ensure prompt reporting of gas leaks posing a hazard to persons or property. To this end, the regulations require pipeline operators to file one-off incident reports about significant gas leaks. A report must be filed on:

- any incident involving a release of gas resulting in death, personal injury necessitating inpatient hospitalization, property damage of $\$ 50,000$ or more (including the cost of lost gas), or the unintentional loss of three million cubic feet or more of gas;

- any event causing the emergency shutdown of a liquefied natural gas (LNG) facility; or

- any event is otherwise significant in the view of the operator.

These incidents must be reported, by telephone, to the National Response Center as soon as possible but generally within two hours. A written report about the incident must also be filed with the PHMSA within thirty days. This written report must include detailed information about the incident, including its cause and effect. This and/or other information may also have to be provided to state regulators. The requirements in each state are summarized in Appendix 3 to this White Paper.

The PHMSA also collects information about certain safety-related conditions. Each pipeline operator must file, with the PHMSA, a safety-related condition report about any gas pipeline leak constituting an emergency. ${ }^{103}$ However, a report need not be submitted where the leak originates from a pipeline that is located more than 220 yards from any building intended for human occupancy or any place of public assembly.

The PHMSA uses the safety-related condition and incident reports filed by pipeline operators to assess the safety of gas transportation. ${ }^{104}$ Consistent with this use, the focus of reporting is on significant gas leaks and other incidents posing a risk to persons or property. ${ }^{105}$ By way of example, as noted above, pipeline operators must report any incident resulting in death, personal injury, or significant property damage. Notably however, other incidents generally do not have to 
be reported, unless they result in significant gas leakage exceeding three million cubic feet. Smaller gas leaks can, and often do, go unreported.

\section{Other leak reporting requirements}

In addition to one-off incident reports, pipeline operators must also periodically file aggregate leak reports with the PHMSA and state regulators. The PHMSA requires each pipeline operator to file an annual report including, among other things, details of leaks repaired or scheduled for repair during the previous year. ${ }^{106}$ This data is compiled by PHMSA, which publishes yearly summaries of pipeline leaks. ${ }^{107}$

While pipeline operators must report leaks that have been repaired or scheduled for repair, other (unrepaired) leaks can and often do go unreported. This can be a significant portion of all leaks. As discussed in Section III above, the PHMSA regulations only require pipeline operators to repair leaks posing a hazard to persons or property. Other non-hazardous leaks can be, and often are, left unrepaired. These unrepaired leaks do not have to be listed in the annual reports filed with PHMSA.

Seeking to address this gap in reporting, eight states have adopted their own rules requiring pipeline operators to report on all gas leaks, both hazardous and non-hazardous. ${ }^{108}$ By way of example, in Maine and New Hampshire, operators must file monthly reports showing all leaks existing at the beginning of the month, leaks detected during the month, and leaks repaired or awaiting repair at the end of the month. ${ }^{109}$ Similar information must be reported semi-annually by operators in Texas. ${ }^{110}$

Most periodic leak reports filed by pipeline operators contain little information on the cause and/or consequences of gas leakage. By way of example, in the annual reports filed with PHMSA, operators generally only specify the number of leaks repaired during the previous year or scheduled for repair at year end. The reports typically do not quantify the amount of gas released through those leaks. Even where releases are quantified, the quantification is typically not based on direct measurement of the leaks.

Regulators generally do not require direct measurement of gas losses through pipeline leaks. By way of example, as part of the EPA's Greenhouse Gas Reporting Program, certain pipeline operators must report methane emissions due to system leaks and other causes. ${ }^{111}$ Notably however, in reporting emissions due to leakage from pipelines, operators are not required directly measure the size of leaks. ${ }^{112}$ Rather, operators may rely on estimates, calculated based on average emission rates developed in the 1990s. ${ }^{113}$

18 | Safety First, Environment Last | September 2015 
A 1996 study by the Gas Research Institute (GRI) and EPA developed emissions factors (EFs) for various components in the natural gas industry. ${ }^{114}$ Those EFs are multiplied by an activity factor, reflecting the population of each component type, to estimate overall emissions. ${ }^{115}$ Those estimates may not, however, accurately reflect the volume of methane emitted.

Recent research suggests that the distribution of methane emissions from natural gas system is highly skewed, with most originating from a small number of "super-emitters." A 2015 study, quantifying methane emissions from gas distribution pipelines, found that just three large leaks accounted for fifty percent of measured emissions. ${ }^{116}$ Another study, focusing on leaks from transmission pipelines, found that up to seventy-five percent to methane emissions may originate from just five percent of leaks. ${ }^{117}$ With this type of distribution, average emission rates are unlikely to accurately reflect the volume of methane emitted from any one leak. ${ }^{118}$ It is, therefore, important that pipeline operators directly measure the volume of gas lost through leaks.

Various technologies can be used to measure gas losses due to leaks. By way of example, flame ionization devices and other sampling instruments can measure radiation or hydrocarbon vapors in the air surrounding a pipeline. ${ }^{119}$ Based on those measurements, operators can calculate the volume of gas leaking from the pipeline. Similarly, electronic tools can be used to estimate gas leakage based on changes in pipeline volume and pressure. ${ }^{120}$

Many of these technologies are now commercially available and, as such, could be used by pipeline operators to measure gas leaks. Such measurements would provide the PHMSA with useful data regarding the extent of gas leakage, enabling it to produce more accurate leak reports. Moreover, the data may also prove useful for other agencies. The EPA, for example, could use the data to improve the accuracy of its greenhouse gas inventory which is currently produced using data collected through the greenhouse gas reporting program. Given the shortcomings in that program, the EPA should be given access to all data on pipeline leaks collected by the PHMSA and/or state agencies.

\section{Recommendation}

As the foregoing discussion illustrates, there is a need for enhanced reporting of pipeline leaks, to enable more accurate assessment of the extent of gas leakage. The PHMSA's current regulations are insufficient as, while pipeline operators are required to report the number of leaks repaired each year, there is no requirement to report other unrepaired leaks. Moreover, operators generally do not have to quantify the amount of gas lost through such leaks. In the future, the PHMSA should require pipeline operators to measure the volume of gas lost through all leaks, regardless of their repair status. The results of these measurements should be periodically reported to the PHMSA.

19 | Safety First, Environment Last | September 2015 


\section{Conclusion}

Recent technological advancements have enabled the development of vast natural gas reserves previously considered inaccessible. As development expands, natural gas is increasingly being substituted for coal in electricity generation and other applications, leading to improved air quality. Switching from coal- to natural gas-fired generation lowers emissions of mercury and other air toxins that endanger public health. Moreover, it can also help to reduce climatedamaging greenhouse gas emissions. These reductions are, however, frequently offset by emissions during natural gas production.

Methane - the primary component of natural gas and a potent greenhouse gas - is released throughout the production process. Most releases occur during gas transportation, as a result of leakage from pipelines that have corroded over time or been damaged by natural or other forces. Despite this, however, existing regulation does not adequately address pipeline leaks.

The regulations, adopted by the PHMSA, focus primarily on controlling leaks that pose a hazard to public safety. The PHMSA regulations do little to control other leaks which, though not hazardous to the public, may have adverse impacts on the environment. This is despite the requirement, in PHMSA's authorizing legislation, that the regulations be "designed to meet the need for gas pipeline safety... and protecting the environment."

Consistent with this legislative requirement, the regulations should be updated to provide for improved management of pipeline leaks as follows:

- Pipelines should be regularly inspected for leaks. All pipelines, regardless of location, should be inspected for leaks annually. More frequent inspections may need to be conducted on high-risk pipelines.

- Pipeline system leaks should be repaired promptly. Large leaks, considered hazardous to the public or damaging to the environment, should be repaired immediately upon discovery. Smaller leaks should be repaired within one year after discovery.

- Gas losses due to pipeline leaks should be accurately measured. The results of those measurements should be reported periodically to state and federal regulators.

20 | Safety First, Environment Last | September 2015 


\section{Appendix 1: State leak detection requirements}

The PHMSA regulations set out minimum standards for the construction, operation, and maintenance of pipelines. As a supplement to these minimum standards, individual states may adopt additional or more stringent requirements on pipelines within their respective jurisdictions. The table below outlines additional requirements, exceeding the minimum federal standards, for leak detection in each state. ${ }^{121}$

\begin{tabular}{|c|c|c|c|}
\hline Jurisdiction & \multicolumn{2}{|c|}{ Requirement to conduct pipeline testing } & Procedures for conducting tests \\
\hline Alabama & No additional requirements. & No additional requirements. & No additional requirements. \\
\hline Alaska & \multicolumn{3}{|l|}{ No state pipeline safety regulations. } \\
\hline Arizona & $\begin{array}{l}\text { All transmission pipelines must be } \\
\text { surveyed for leaks twice per year, } \\
\text { at } 7.5 \text { month intervals. }\end{array}$ & $\begin{array}{l}\text { All master meter systems } 122 \text { must } \\
\text { be surveyed annually, at } 15 \text { month } \\
\text { intervals. }\end{array}$ & $\begin{array}{l}\text { Leak surveys must be conducted in accordance } \\
\text { with ASME Guide for Gas Transmission and } \\
\text { Distribution Pipeline System, Guide Material, } \\
\text { Appendix G-11-1983.123 }\end{array}$ \\
\hline Arkansas & No additional requirements. & No additional requirements. & $\begin{array}{l}\text { Leak surveys must ensure detection, location, } \\
\text { evaluation, and classification of leaks. Surveys } \\
\text { must be conducted using flame ionization } \\
\text { detectors, combustible gas indicators, or other leak } \\
\text { detector equipment. }{ }^{124}\end{array}$ \\
\hline Colorado & No additional requirements. & No additional requirements. & No additional requirements. \\
\hline
\end{tabular}

21 | Safety First, Environment Last | September 2015 


\begin{tabular}{|c|c|c|c|}
\hline Jurisdiction & \multicolumn{2}{|c|}{ Requirement to conduct pipeline testing } & Procedures for conducting tests \\
\hline Connecticut & \multicolumn{2}{|c|}{$\begin{array}{l}\text { Pipeline operators must have a systematic inspection program for } \\
\text { detecting leaks and observing conditions that might cause or be } \\
\text { connected with leaks. }\end{array}$} & $\begin{array}{l}\text { Inspections may involve vegetation surveys, line } \\
\text { patrolling, and/or the testing of bar-holes and } \\
\text { utility manholes with a combustible gas } \\
\text { indicator. }{ }^{126}\end{array}$ \\
\hline Delaware & No additional requirements. & No additional requirements. & No additional requirements. \\
\hline $\begin{array}{l}\text { District of } \\
\text { Columbia }\end{array}$ & No additional requirements. & $\begin{array}{l}\text { Service lines in places of public } \\
\text { assembly must be surveyed for } \\
\text { leaks annually. } \\
\text { All other pipelines must be } \\
\text { surveyed every } 3 \text { years. }\end{array}$ & $\begin{array}{l}\text { Leak surveys in business districts must include } \\
\text { tests of the atmosphere in utility manholes, at } \\
\text { cracks in pavement, and at other locations } \\
\text { providing an opportunity to find leaks. } \\
\text { Surveys of service lines in places of public } \\
\text { assembly must be conducted using Hydrogen } \\
\text { Flame Ionization Combustible Gas Indictor, or other } \\
\text { similar methods. }{ }^{127}\end{array}$ \\
\hline Florida & \multicolumn{2}{|c|}{$\begin{array}{l}\text { Leak surveys must be conducted annually, at } 15 \text { month intervals, in the } \\
\text { following areas: } \\
\text { - } \quad \text { principal business districts, master meter systems, and places where } \\
\text { the public is known to congregate frequently; } \\
\text { - where pipeline facilities, including service lines, are located under } \\
\text { surfaces of such construction that little opportunity is afforded for a } \\
\text { leak to vent safely. } \\
\text { In other areas, surveys must be conducted every } 3 \text { years on bare } \\
\text { metallic, galvanized steel, and coated tubing pipelines and every } 5 \text { years } \\
\text { on the remainder of the pipeline system. }\end{array}$} & $\begin{array}{l}\text { Leak surveys must be conducted using gas detector } \\
\text { instruments. }{ }^{128}\end{array}$ \\
\hline Georgia & No additional requirements. & No additional requirements. & No additional requirements. \\
\hline Hawaii & \multicolumn{3}{|c|}{ No state regulations governing pipeline safety. } \\
\hline Idaho & No additional requirements. & No additional requirements. & No additional requirements. \\
\hline Illinois & No additional requirements. & No additional requirements. & No additional requirements. \\
\hline
\end{tabular}

22 | Safety First, Environment Last | September 2015 


\begin{tabular}{|c|c|c|c|}
\hline Jurisdiction & \multicolumn{2}{|c|}{ Requirement to conduct pipeline testing } & Procedures for conducting tests \\
\hline Indiana & No additional requirements. & $\begin{array}{l}\text { Pipelines in areas of high } \\
\text { occupancy buildings, built-up } \\
\text { residential areas with continuous } \\
\text { pavement, and other designated } \\
\text { areas must be surveyed for leaks } \\
\text { annually, at } 15 \text { month intervals. }\end{array}$ & No additional requirements. ${ }^{129}$ \\
\hline Iowa & No additional requirements. & No additional requirements. & No additional requirements. \\
\hline
\end{tabular}




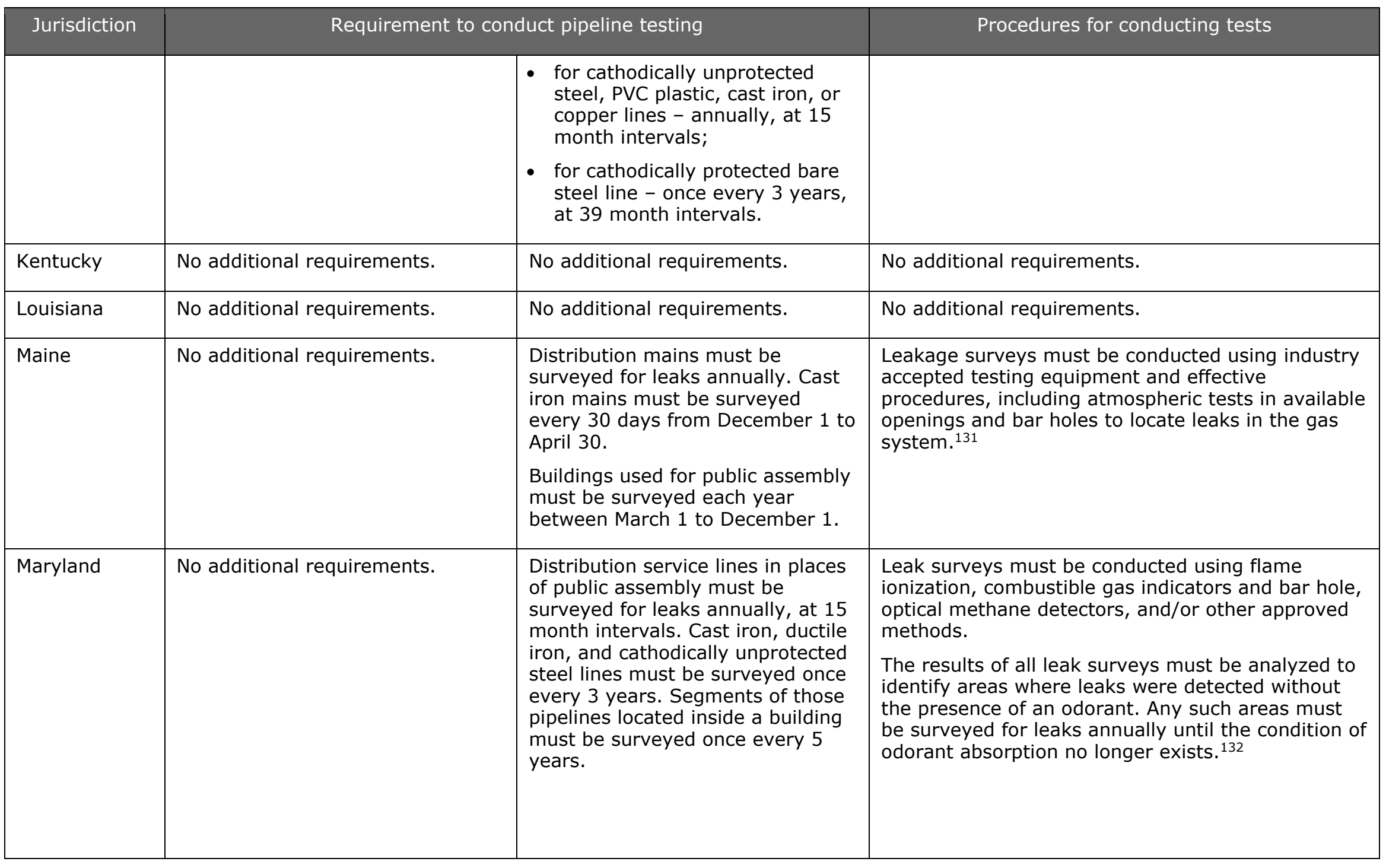




\begin{tabular}{|c|c|c|c|}
\hline Jurisdiction & \multicolumn{2}{|c|}{ Requirement to conduct pipeline testing } & Procedures for conducting tests \\
\hline Massachusetts & No additional requirements. & $\begin{array}{l}\text { Pipelines in business districts must } \\
\text { be surveyed at } 12 \text { month } \\
\text { intervals. Pipelines outside } \\
\text { business districts must be } \\
\text { surveyed at } 24 \text { month intervals. } \\
\text { Surveys must be conducted } \\
\text { annually at schools, churches, } \\
\text { theatres, and arenas. }\end{array}$ & $\begin{array}{l}\text { Distribution pipelines must be surveyed using } \\
\text { combustible gas indicators, flame ionization } \\
\text { equipment, infra-red equipment, or other industry } \\
\text { accepted equipment, bar tests, vegetation surveys, } \\
\text { and/or pressure drop tests. } \\
\text { Surveys conducted in business districts must } \\
\text { include tests of the atmosphere in manholes, at } \\
\text { cracks in pavement, and at other locations } \\
\text { providing an opportunity to find leaks. } \\
\text { Surveys conducted at schools, churches, theatres, } \\
\text { and arenas must include tests for gas leakage and } \\
\text { visual inspection of gas facilities. }{ }^{133}\end{array}$ \\
\hline Michigan & $\begin{array}{l}\text { Transmission lines operating at } 40 \\
\text { percent or more of specified } \\
\text { minimum yield strength must be } \\
\text { patrolled } 12 \text { times per year, at } 6 \\
\text { week intervals. }\end{array}$ & No additional requirements. & $\begin{array}{l}\text { Leakage surveys must involve a systematic pipeline } \\
\text { inspection. } \\
\text { Leak tests conducted on distribution service lines } \\
\text { must last for at least } 10 \text { minutes. }{ }^{134}\end{array}$ \\
\hline Minnesota & No additional requirements. & No additional requirements. & No additional requirements. \\
\hline Mississippi & No additional requirements. & No additional requirements. & No additional requirements. \\
\hline Missouri & $\begin{array}{l}\text { All transmission lines in class } 3 \\
\text { locations must be surveyed for } \\
\text { leaks twice per year, at } 7.5 \text { month } \\
\text { intervals. } \\
\text { All transmission lines in class } 4 \\
\text { locations must be surveyed for } \\
\text { leaks } 4 \text { times per year, at } 4.5 \\
\text { month intervals. }\end{array}$ & $\begin{array}{l}\text { Unprotected steel pipelines outside } \\
\text { of business districts must be } \\
\text { surveyed for leaks annually, at } 15 \\
\text { month intervals. All other pipelines } \\
\text { outside of business districts must } \\
\text { be surveyed every } 3 \text { years, at } 39 \\
\text { month intervals. }\end{array}$ & $\begin{array}{l}\text { Leakage surveys of distribution pipelines located } \\
\text { within business districts must include tests of the } \\
\text { atmosphere in utility manholes, at cracks in } \\
\text { pavement, and at other locations providing an } \\
\text { opportunity to find leaks. }{ }^{135}\end{array}$ \\
\hline Montana & No additional requirements. & No additional requirements. & No additional requirements. \\
\hline Vebraska & No additional requirements. & No additional requirements. & No additional requirements. \\
\hline
\end{tabular}

25 | Safety First, Environment Last | September 2015 
Jurisdiction

\begin{tabular}{|c|c|c|}
\hline Nevada & No additional requirements. & No additional requirements. \\
\hline $\begin{array}{l}\text { New } \\
\text { Hampshire }\end{array}$ & No additional requirements. & $\begin{array}{l}\text { Distribution mains in locations or } \\
\text { on structures where physical } \\
\text { movement or external loading } \\
\text { could cause failure or leakage } \\
\text { must be patrolled } 3 \text { times per } \\
\text { year. } \\
\text { Cast iron distribution mains in } \\
\text { business districts } 136 \text { must be } \\
\text { surveyed for leaks on a repeated } \\
\text { basis during the months when } \\
\text { frost is in the ground. } \\
\text { A gas detector survey of buildings } \\
\text { used for public assembly must be } \\
\text { conducted each year between } \\
\text { March } 1 \text { and December } 1 .\end{array}$ \\
\hline New Jersey & $\begin{array}{l}\text { Transmission lines in Class } 3 \text { and } 4 \\
\text { locations must be patrolled } \\
\text { monthly. }\end{array}$ & $\begin{array}{l}\text { Bare and coated cathodically } \\
\text { unprotected steel distribution lines } \\
\text { must be surveyed more frequently } \\
\text { (than required under the federal } \\
\text { regulations) as deemed necessary } \\
\text { by the pipeline operator based on } \\
\text { leak history, leaks discovered by } \\
\text { the public, and operating pressure. }\end{array}$ \\
\hline New Mexico & No additional requirements. & No additional requirements. \\
\hline
\end{tabular}

Procedures for conducting tests

No additional requirements.

A survey of buildings used for public assembly must test areas around entrances, inside the foundation well, at conduit and cable entrances below ground, and at cracks or breaks in the foundation wall where gas seepage might enter the basement. Exposed piping from the service entrance to the outlet side of the meter must also be tested. ${ }^{137}$

Combustible gas detecting instruments must be used in the investigation of suspected leaks. A pipeline operator must assign combustible gas detecting instruments to all personnel involved in leak investigation. The instruments must be properly maintained and periodically calibrated in accordance with the manufacturer's specifications.

Leak detection surveys of bare and coated cathodically unprotected steel distribution pipelines must be conducted using leak detection equipment that is at least as reliable and sensitive as flame ionization. ${ }^{138}$

Leak surveys on transmission lines must be conducted using leak detection equipment. ${ }^{139}$

26 | Safety First, Environment Last | September 2015 


\begin{tabular}{|c|c|c|c|}
\hline Jurisdiction & Requiremen & duct pipeline testing & Procedures for conducting tests \\
\hline New York & No additional requirements. & $\begin{array}{l}\text { Distribution pipelines operating at } \\
125 \text { pounds per square inch gage } \\
\text { (PSIG) or more must be patrolled: } \\
\text { - if the pipeline is in a Class } 3 \\
\text { location - twice per year (and } \\
\quad 4 \text { times per year at highway } \\
\text { and railroad crossings); } \\
\text { - if the pipeline is in a Class } 4 \\
\quad \text { location - } 4 \text { times per year. } \\
\text { Distribution mains in places or on } \\
\text { structures where physical } \\
\text { movement or external loading } \\
\text { could cause failure or leakage } \\
\text { must be patrolled } 4 \text { times per } \\
\text { year. } \\
\text { Distribution lines operating at } 125 \\
\text { PSIG or more in Class } 3 \text { or } 4 \\
\text { locations must be surveyed for } \\
\text { leaks annually, at } 15 \text { month } \\
\text { intervals. }\end{array}$ & $\begin{array}{l}\text { Leak investigations must be conducted by drilling } \\
\text { or boring and testing the atmosphere in the holes } \\
\text { and other available openings with a properly } \\
\text { calibrated combustible gas indicator or other } \\
\text { approved equivalent device. } \\
\text { Leak surveys must be undertaken systematically } \\
\text { using an approved instrument which continuously } \\
\text { analyses atmospheric samples near ground level } \\
\text { and is capable of detecting the presence of gas in } \\
\text { parts per million in air. Any instrument used in } \\
\text { leakage surveys must be regularly tested against a } \\
\text { known sample or in accordance with the } \\
\text { manufacturer's recommended. } \\
\text { Leak surveys of distribution systems in business } \\
\text { districts must include tests of the atmosphere of } \\
\text { accessible manholes, at cracks in pavement, at the } \\
\text { curbline, in the sidewalk, and at other locations } \\
\text { where it would be reasonable to expect a gas leak } \\
\text { to be found.140 }\end{array}$ \\
\hline North Carolina & No additional requirements. & No additional requirements. & No additional requirements. \\
\hline North Dakota & No additional requirements. & No additional requirements. & No additional requirements. \\
\hline Ohio & No additional requirements. & No additional requirements. & $\begin{array}{l}\text { Surveys must be conducted using leak detection } \\
\text { equipment, being equipment capable of detecting } \\
\text { and measuring the concentration of gas in the } \\
\text { air. }{ }^{141}\end{array}$ \\
\hline Oklahoma & No additional requirements. & No additional requirements. & No additional requirements. \\
\hline Oregon & No additional requirements. & No additional requirements. & No additional requirements. \\
\hline
\end{tabular}

27 | Safety First, Environment Last | September 2015 


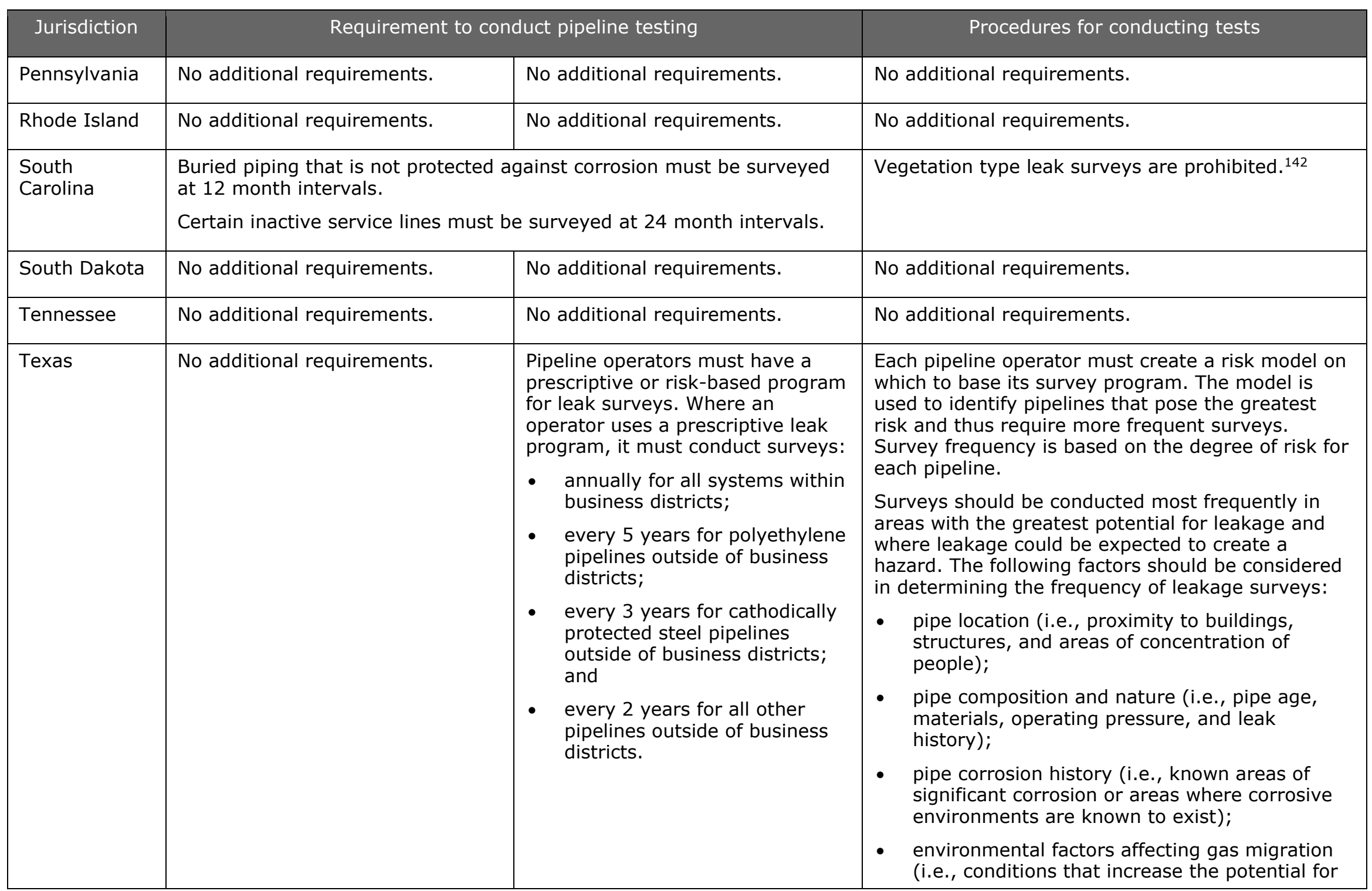

28 | Safety First, Environment Last | September 2015 


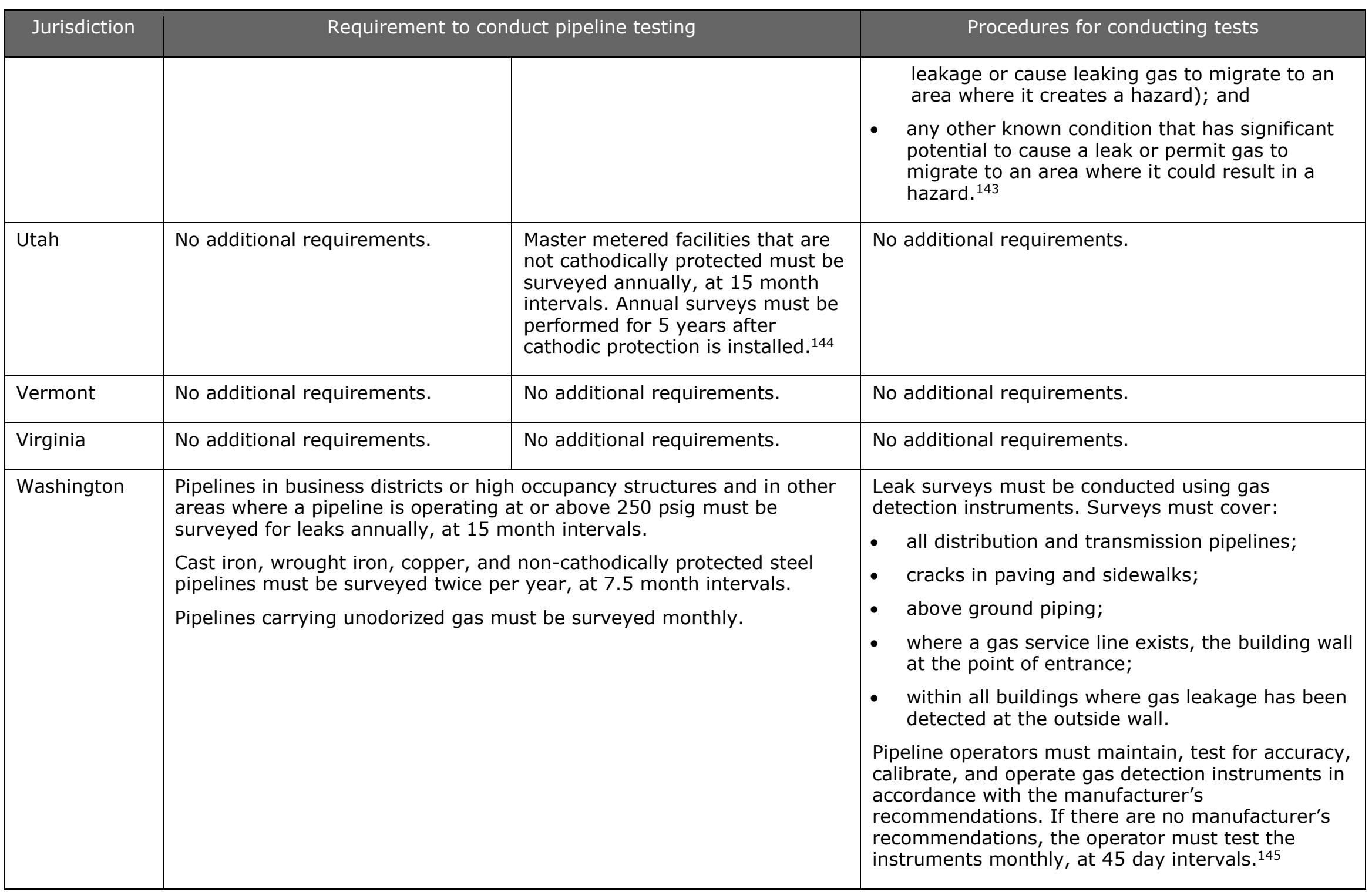

29 | Safety First, Environment Last | September 2015 


\begin{tabular}{|l|l|l|l|}
\hline \multicolumn{1}{|c|}{ Jurisdiction } & \multicolumn{2}{|c|}{ Requirement to conduct pipeline testing } & \multicolumn{1}{c|}{ Procedures for conducting tests } \\
\hline West Virginia & No additional requirements. & No additional requirements. & No additional requirements. \\
\hline Wisconsin & No additional requirements. & $\begin{array}{l}\text { Two leak surveys must be } \\
\text { conducted over street openings in } \\
\text { business districts each year. } \\
\text { Buildings used for public } \\
\text { gatherings must be surveyed } \\
\text { annually, at 15 month intervals. } \\
\text { Mains in incorporated cities must } \\
\text { be surveyed annually, at 15 month } \\
\text { intervals. Mains in unincorporated } \\
\text { cities must be surveyed every } 2 \\
\text { years, at 27 month intervals. }\end{array}$ & $\begin{array}{l}\text { Leakage surveys of mains in unincorporated cities } \\
\text { and villages must be conducted using a continuous- } \\
\text { sampling instrument capable of detecting and } \\
\text { measuring combustible gas in air concentrations of } \\
100 \text { parts per million. Alternatively, the survey may } \\
\text { be conducted using mobile flame ionization or } \\
\text { infrared gas detection units. }\end{array}$ \\
\hline Wyoming & No additional requirements. & No additional requirements. & No additional requirements. \\
\hline
\end{tabular}




\section{Appendix 2: State leak repair requirements}

The table below outlines additional requirements, in excess the minimum federal standards, for leak classification and repair in each state. ${ }^{147}$

\begin{tabular}{|c|c|c|}
\hline Jurisdiction & Leak classification requirements & Leak repair requirements \\
\hline Alabama & No additional requirements. & No additional requirements. \\
\hline Alaska & No state pipeline safety regulations. & \\
\hline Arizona & $\begin{array}{l}\text { Leaks must be classified in accordance with ASME Guide for } \\
\text { Gas Transmission and Distribution Pipeline System, Guide } \\
\text { Material, Appendix G-11-1983. }\end{array}$ & $\begin{array}{l}\text { Grade } 2 \text { or } 3 \text { leaks on underground transmission pipelines must } \\
\text { be repaired upon discovery or within } 1 \text { year thereafter. }{ }^{148}\end{array}$ \\
\hline Arkansas & $\begin{array}{l}\text { Leaks must be classified as follows: } \\
\text { - Class 1: A leak that poses an existing or probable hazard to } \\
\text { persons or property and requires immediate repair or } \\
\text { continuous action until the hazard no longer exists. } \\
\text { Class 2: A leak that is considered non-hazardous at the } \\
\text { time of detection, but could become hazardous if repair is } \\
\text { not accomplished in a reasonable length of time. } \\
\text { - Class 3: A leak that is non-hazardous at the time of } \\
\text { detection and can be expected to remain non-hazardous. } \\
\text { In classifying leaks, pipeline operators must consider the } \\
\text { quantity of gas escaping; the location of the escaping gas; and } \\
\text { the areas to which escaping gas may spread. Leaks may be } \\
\text { reclassified. }\end{array}$ & $\begin{array}{l}\text { Class } 1 \text { leaks must be repaired immediately. } \\
\text { Class } 2 \text { leaks must be repaired as soon as possible, but within } 5 \\
\text { months of discovery. } \\
\text { Class } 3 \text { leaks must be repaired as time and expenditures permit. } \\
\text { Class } 3 \text { leaks should be re-evaluated during the next survey. }{ }^{149}\end{array}$ \\
\hline California & No additional requirements. & No additional requirements. \\
\hline Colorado & No additional requirements. & No additional requirements. \\
\hline Connecticut & No additional requirements. & No additional requirements. \\
\hline
\end{tabular}

31 | Safety First, Environment Last | September 2015 


\begin{tabular}{|c|c|c|}
\hline Jurisdiction & Leak classification requirements & Leak repair requirements \\
\hline Florida & $\begin{array}{l}\text { Leaks must be classified as follows: } \\
\text { - Grade 1: A leak that represents an existing or probable } \\
\text { hazard to persons or buildings. } \\
\text { - Grade 2: A leak that is not a threat to persons or property } \\
\text { at the time of detection, but justifies scheduled repair } \\
\text { based on potential future hazard. } \\
\text { - Grade 3: A leak that is not a threat to persons and property } \\
\text { and is not expected to become so. }\end{array}$ & $\begin{array}{l}\text { Grade } 1 \text { leaks require prompt action. Continuous action must be } \\
\text { taken until the leak is no longer hazardous. } \\
\text { Grade } 2 \text { leaks must be repaired within } 90 \text { days of location. } \\
\text { Grade } 3 \text { leaks located aboveground must be repaired within } 90 \\
\text { days of location. Grade } 3 \text { leaks located underground must be } \\
\text { reevaluated at least once every } 6 \text { months until repaired. The } \\
\text { frequency of reevaluation must be determined based on the } \\
\text { location and magnitude of the leak. }{ }^{151}\end{array}$ \\
\hline Georgia & $\begin{array}{l}\text { Leaks must be classified as follows: } \\
\text { - Grade 1: A leak that represents an existing or probable } \\
\text { hazard to persons or property and requires immediate } \\
\text { repair or continuous action until conditions are no longer } \\
\text { hazardous. } \\
\text { - Grade 2: A leak that is recognized as being non-hazardous } \\
\text { at the time of detection, but justifies scheduled repair } \\
\text { based on probable future hazardous. } \\
\text { - Grade 3: A leak that is non-hazardous at the time of } \\
\text { detection and can be reasonably expected to remain non- } \\
\text { hazardous. }\end{array}$ & $\begin{array}{l}\text { Class } 1 \text { leaks require prompt action. This may include } \\
\text { implementing an emergency plan, evacuating premises, } \\
\text { blocking off an area, eliminating sources of ignition, venting the } \\
\text { area, stopping the flow of gas, and notifying police and fire } \\
\text { departments. } \\
\text { Grade } 2 \text { leaks should be cleared within } 1 \text { calendar year, but no } \\
\text { later than } 15 \text { months from the date reported. Grade } 2 \text { leaks } \\
\text { should be reevaluated every } 6 \text { months until cleared. } \\
\text { Grade } 3 \text { leaks should be reevaluated during the next survey or } \\
\text { within } 15 \text { months of the date reported (whichever is sooner), } \\
\text { until the leak is re-graded or no longer results in a reading. }{ }^{152}\end{array}$ \\
\hline Hawaii & \multicolumn{2}{|l|}{ No state pipeline safety regulations. } \\
\hline Idaho & No additional requirements. & No additional requirements. \\
\hline [llinois & No additional requirements. & No additional requirements. \\
\hline
\end{tabular}

32 | Safety First, Environment Last | September 2015 


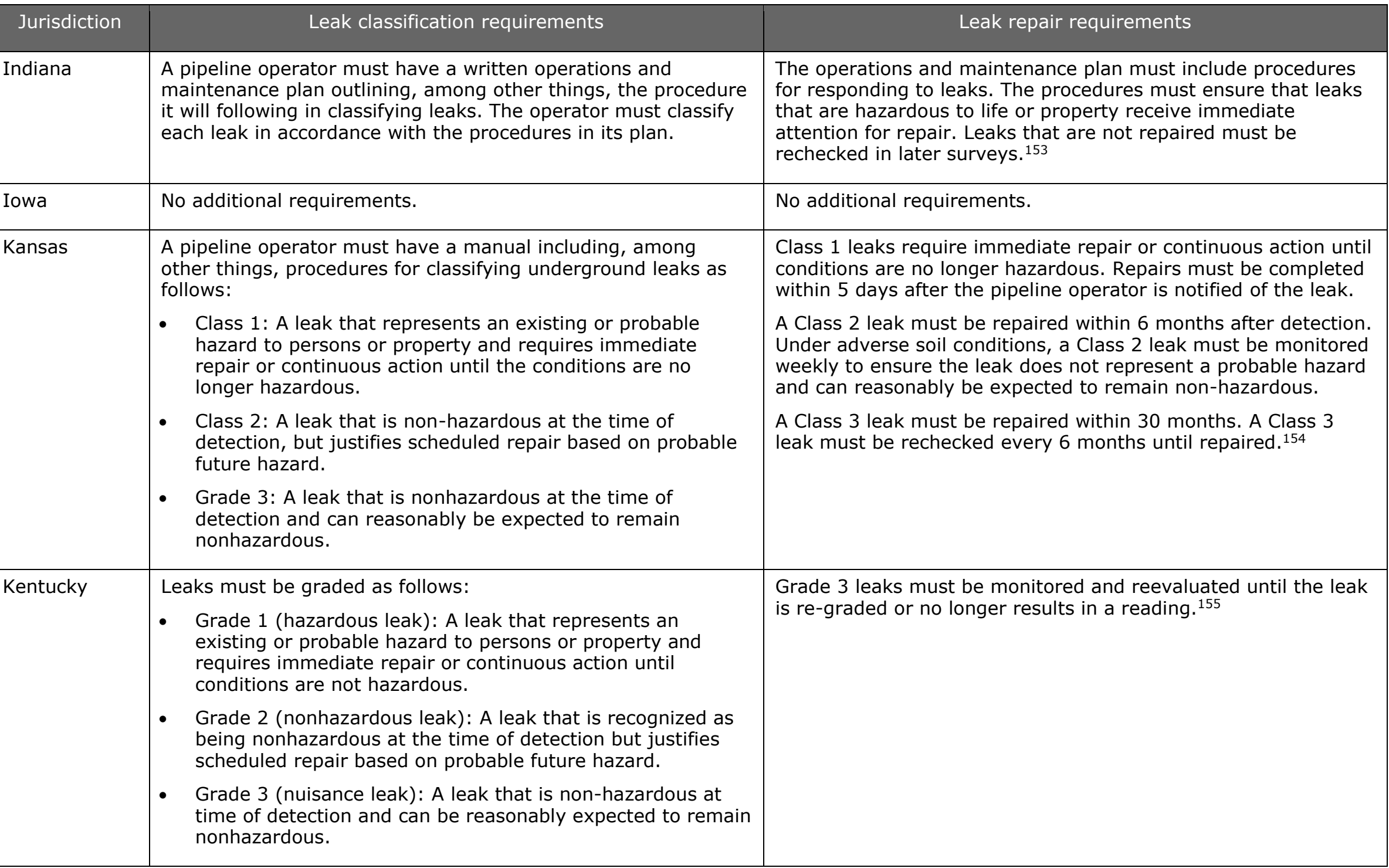

33 | Safety First, Environment Last | September 2015 


\begin{tabular}{|c|c|c|}
\hline Jurisdiction & Leak classification requirements & Leak repair requirements \\
\hline Louisiana & No additional requirements. & $\begin{array}{l}\text { Immediate temporary measures must be taken to protect the } \\
\text { public whenever a leak impairing serviceability is found in a } \\
\text { segment of steel transmission line operating at or above } 40 \\
\text { percent of the SMYS. Permanent repairs must be made as soon } \\
\text { as feasible. }{ }^{156}\end{array}$ \\
\hline Maine & $\begin{array}{l}\text { Leaks must be classified as follows: } \\
\text { - Grade 1: A leak that represents an existing or probable } \\
\text { hazard to persons or property and requires prompt action, } \\
\text { immediate repair, or continuous action until conditions are } \\
\text { no longer hazardous. } \\
\text { - Grade 2: A leak that is recognized as being non-hazardous } \\
\text { at the time of detection, but justifies scheduled repair or } \\
\text { removal within } 6 \text { months or less of detection due to the } \\
\text { probability of its future hazard. } \\
\text { - Grade } 3 \text { leak: A leak that is non-hazardous at the time of } \\
\text { detection and can reasonably be expected to remain non- } \\
\text { hazardous. } \\
\text { A pipeline operator must not downgrade a leak unless it has } \\
\text { been repaired. The operator may upgrade a leak if it becomes } \\
\text { more serious. }\end{array}$ & $\begin{array}{l}\text { A pipeline operator must establish a leak repair priority based } \\
\text { on its evaluation of the location and magnitude of the leak. } \\
\text { Class } 1 \text { leaks require immediate corrective action. This may } \\
\text { include implementing an emergency plan, evacuating premises, } \\
\text { blocking off an area, rerouting traffic, eliminating sources of } \\
\text { ignition, venting the area, and/or notifying emergency } \\
\text { responders. } \\
\text { Certain Grade } 2 \text { leaks, classified as priority } 1 \text { leaks, must be } \\
\text { repaired within } 30 \text { days of detection. Other Grade } 2 \text { leaks must } \\
\text { be reevaluated every } 30 \text { days until repaired and cleared. } \\
\text { A Grade } 3 \text { leak must be repaired within } 24 \text { months of detection, } \\
\text { unless it is located within an approved main replacement } \\
\text { program area, in which case the time for repair is extended to } \\
\text { the scheduled replacement. Grade } 3 \text { leaks must be reevaluated } \\
\text { every } 180 \text { days from the date of discovery, until repaired. } \\
\text { When a leak is upgraded (e.g., from Grade } 2 \text { to } 1 \text { ), the time } \\
\text { period for repair is the remaining time based on its original } \\
\text { classification or the time allowed under the new grade, } \\
\text { whichever is less. }\end{array}$ \\
\hline Maryland & No additional requirements. & No additional requirements. \\
\hline
\end{tabular}

34 | Safety First, Environment Last | September 2015 


\begin{tabular}{|c|c|c|}
\hline Jurisdiction & Leak classification requirements & Leak repair requirements \\
\hline Massachusetts & $\begin{array}{l}\text { Leaks must be classified as follows: } \\
\text { - Grade 1: A leak that represents an existing or probable } \\
\text { hazard to persons or property. } \\
\text { - Grade 2: A leak that is recognized as being non-hazardous } \\
\text { to persons or property at the time of detection, but justifies } \\
\text { schedule repair based on probable future hazard. } \\
\text { - Grade 3: A leak that is recognized as being non-hazardous } \\
\text { to persons or property at the time of detection and can be } \\
\text { reasonably expected to remain non-hazardous. }\end{array}$ & $\begin{array}{l}\text { Grade } 1 \text { leaks must be repaired as immediately as possible and } \\
\text { kept under continuous surveillance until repaired. } \\
\text { A Grade } 2 \text { leak must be repaired within } 12 \text { months from the } \\
\text { date of classification. The leak must be reevaluated once every } \\
6 \text { months until repaired. } \\
\text { A Grade } 3 \text { leak must be reevaluated during the next survey or } \\
\text { within } 12 \text { months from the date last evaluated (whichever is } \\
\text { first) until eliminated. A municipal or state public safety official } \\
\text { may request a reevaluation prior to the next scheduled survey } \\
\text { or sooner than } 12 \text { months of the date last evaluated if he/she } \\
\text { reasonably believes the leak poses a threat to public safety. } \\
\text { A pipeline operator must prioritize repair of leaks detected on or } \\
\text { within } 50 \text { feet of a public or private accredited preschool, } \\
\text { accredited Head Start facility, or elementary, vocational or } \\
\text { secondary school. }{ }^{158}\end{array}$ \\
\hline Michigan & $\begin{array}{l}\text { An operator's maintenance manual may provide for the } \\
\text { classification of leaks. }\end{array}$ & $\begin{array}{l}\text { Leaks must be evaluated to determine whether they require } \\
\text { immediate repair, repair within } 1 \text { year, or surveillance. } \\
\text { Immediate action must be taken with respect to a leak that, due } \\
\text { to its location or relative magnitude, constitutes a hazard or } \\
\text { potential hazard to the public or buildings. A leak that does not } \\
\text { constitute an immediate hazard, but requires scheduled repair } \\
\text { under the operator's maintenance manual, must be repaired } \\
\text { within } 1 \text { year. Other gas leaks must reevaluated at least once } \\
\text { each calendar year, at intervals not exceeding } 15 \text { months. }{ }^{159}\end{array}$ \\
\hline Minnesota & No additional requirements. & No additional requirements. \\
\hline Mississippi & No additional requirements. & No additional requirements. \\
\hline
\end{tabular}

35 | Safety First, Environment Last | September 2015 


\begin{tabular}{|c|c|c|}
\hline Jurisdiction & Leak classification requirements & Leak repair requirements \\
\hline Missouri & $\begin{array}{l}\text { Leaks must be classified as follows: } \\
\text { - Class 1: a leak which, due to its location and/or magnitude, } \\
\text { constitutes an immediate hazard to buildings and/or the } \\
\text { public. } \\
\text { - Class 2: A leak that does not constitute an immediate } \\
\text { hazard to a building or to the general public, but is of a } \\
\text { nature requiring action as soon as possible: } \\
\text { - Class 3: A leak that does not constitute a hazard to } \\
\text { buildings or to the public, but is of a nature requiring } \\
\text { routine action. } \\
\text { - Class } 4: \text { A confined or localized leak which is nonhazardous. } \\
\text { A Class } 1 \text { leak may be reclassified to Class } 2 \text { if the pipeline } \\
\text { operator determines that, as a result of venting of the area, } \\
\text { the hazard posed by the leak has been eliminated. }\end{array}$ & $\begin{array}{l}\text { Class } 1 \text { leaks require immediate corrective action. This may } \\
\text { include venting at or near the leak. A class } 1 \text { leak that, after } \\
\text { venting, is reclassified to a Class } 2 \text { leak must be repaired within } \\
15 \text { days. Such leaks must be rechecked daily until repaired. } \\
\text { Class } 2 \text { leaks in sanitary sewers, tunnels, or confined areas } \\
\text { must be repaired or reclassified within } 15 \text { days. Class } 2 \text { leaks in } \\
\text { other areas must be repaired within } 45 \text { days. However, if the } \\
\text { pipeline is due for replacement within } 1 \text { year, the leak need not } \\
\text { be repaired. Class } 2 \text { leaks must be rechecked every } 15 \text { days } \\
\text { until repaired. } \\
\text { Class } 3 \text { leaks must be repaired within } 5 \text { years. Class } 3 \text { leaks } \\
\text { must be rechecked twice per calendar year, at intervals not } \\
\text { exceeding } 6.5 \text { months, until repaired. } \\
\text { No action is required to address Class } 4 \text { leaks. }{ }^{160}\end{array}$ \\
\hline Montana & No additional requirements. & No additional requirements. \\
\hline Nebraska & No additional requirements. & No additional requirements. \\
\hline Nevada & No additional requirements. & No additional requirements. \\
\hline
\end{tabular}

36 | Safety First, Environment Last | September 2015 
Jurisdiction

\begin{tabular}{|c|c|c|}
\hline $\begin{array}{l}\text { New } \\
\text { Hampshire }\end{array}$ & $\begin{array}{l}\text { Leaks must be classified as follows: } \\
\text { - Class I: A leak that represents an existing or probable } \\
\text { hazard to persons or property and requires repairs within } \\
24 \text { hours or continuous action until conditions are no longer } \\
\text { hazardous. } \\
\text { - Class II: A leak that is recognized as being non-hazardous } \\
\text { at the time of detection, but requires scheduled repair } \\
\text { within } 6 \text { months or before the end of the calendar year } \\
\text { based on probable future hazard of any degree. } \\
\text { - Class III: A leak that is non-hazardous at the time of } \\
\text { detection and can reasonably be anticipated to remain non- } \\
\text { hazardous. } \\
\text { When evaluating leaks, a pipeline operator must consider: } \\
\text { - the amount and migration of gas; } \\
\text { - the proximity of gas to buildings and subsurface structures; } \\
\text { - the extent of pavement, including wall-to-wall paving that } \\
\text { includes areas covered in gravel or grass; and } \\
\text { - soil type and conditions, such as frost cap, moisture, and } \\
\text { natural venting. } \\
\text { A pipeline operator must not, in each calendar year, downgrade } \\
\text { from Class II to Class III more than } 6 \text { leaks or } 5 \text { percent of all } \\
\text { outstanding leaks in a given class (whichever is less). }\end{array}$ & $\begin{array}{l}\text { Class I leaks require immediate corrective action. This may } \\
\text { include implementing an emergency plan, evacuating premises, } \\
\text { blocking off an area, rerouting traffic, eliminating sources of } \\
\text { ignition, venting the area, stopping the flow of gas, or notifying } \\
\text { emergency responders. All Class I leaks must be repaired within } \\
24 \text { hours. } \\
\text { A Class II leak must be repaired within } 6 \text { months or before the } \\
\text { end of the calendar year in which it is detected. A Class II leak } \\
\text { must be rechecked once every } 60 \text { days during the months of } \\
\text { April to December and no greater than every } 30 \text { days during the } \\
\text { months of January to March. } \\
\text { A Class III leak must be reevaluated at least once per calendar } \\
\text { year. At least one reevaluation must be performed between } \\
\text { September } 1 \text { and December } 15 \text { each calendar year. }{ }^{161} \\
\text { A cap may be placed on the total number of unrepaired leaks. }{ }^{162}\end{array}$ \\
\hline New Jersey & No additional requirements. & $\begin{array}{l}\text { A pipeline operator must take such corrective action to address } \\
\text { leaks as is required by the facts and circumstances. }{ }^{163}\end{array}$ \\
\hline
\end{tabular}

37 | Safety First, Environment Last | September 2015 


\begin{tabular}{|c|c|c|}
\hline Jurisdiction & Leak classification requirements & Leak repair requirements \\
\hline New Mexico & $\begin{array}{l}\text { Leaks must be classified as follows: } \\
\text { - Grade } 1 \text { or C (Hazardous Leak): A leak that, due to its } \\
\text { location or magnitude, constitutes an immediate hazard. } \\
\text { - Grade } 2 \text { or B (Potentially Hazardous Leak): A leak that does } \\
\text { not constitute an immediate hazard, but may become } \\
\text { hazardous if not repaired within a reasonable time period. } \\
\text { - Grade } 3 \text { or A (Non-hazardous Leak): A leak that does not } \\
\text { constitute a hazard and shows no indication of becoming } \\
\text { hazardous before routine scheduled repair. }\end{array}$ & Pipeline operators must have a plan for the repair of leaks. ${ }^{164}$ \\
\hline New York & $\begin{array}{l}\text { Leaks must be classified as follows: } \\
\text { - Type 1: A leak which, due to its location and/or relative } \\
\text { magnitude, constitutes a potentially hazardous condition to } \\
\text { the public or buildings. } \\
\text { - Type 2A: A leak which does not present an immediately } \\
\text { hazardous condition to the public or buildings, but is of a } \\
\text { nature requiring frequent surveillance and scheduled repair. } \\
\text { - Type 2: A leak that does not present an immediate } \\
\text { hazardous condition to the public or buildings, but is of a } \\
\text { nature requiring scheduled repair. } \\
\text { - Type 3: A leak that is not immediately hazardous at the } \\
\text { time of detection and can be reasonably expected to remain } \\
\text { that way. } \\
\text { A pipeline operator may downgrade leaks. Prior to downgrading } \\
\text { a leak without repair, one additional surveillance at the normal } \\
\text { interval is required to verify that a lower class of hazard exists. } \\
\text { Leaks on exposed piping or facilities need not be classified. }\end{array}$ & $\begin{array}{l}\text { Type } 1 \text { leaks require immediate and continuous action until } \\
\text { conditions are no longer hazardous. Completion of repairs must } \\
\text { be scheduled on a regular day-after-day basis or the condition } \\
\text { kept under daily surveillance until the leak has been addressed. } \\
\text { Type } 2 \text { A leaks must be repaired within } 6 \text { months. They must be } \\
\text { reevaluated every } 2 \text { weeks until repaired. } \\
\text { Type } 2 \text { leaks must be repaired within } 1 \text { year. They must be } \\
\text { reevaluated every } 2 \text { months until repaired. }{ }^{165} \\
\text { Type } 3 \text { leaks must be reevaluated during the next scheduled } \\
\text { leakage survey or annually (whichever is less). } \\
\text { When a leak is reclassified to a higher level, the time period for } \\
\text { repair is the remaining time based on its original classification or } \\
\text { the time allowed for its new classification (whichever is less). } \\
\text { When a leak is reclassified to a lower level, the originate date of } \\
\text { discovery determines the time period for repair. In no case shall } \\
\text { the time limit for repair exceed one year from the date of } \\
\text { discovery. } \\
\text { A cap may be placed on the total number of unrepaired leaks. }{ }^{166}\end{array}$ \\
\hline North Carolina & $\begin{array}{l}\text { Leaks must be classified in accordance with the ASME Guide for } \\
\text { Gas Piping Systems - Appendix G-K (Leakage Classification). }\end{array}$ & No additional requirements. ${ }^{167}$ \\
\hline
\end{tabular}

38 | Safety First, Environment Last | September 2015 


\begin{tabular}{|c|c|c|}
\hline Jurisdiction & Leak classification requirements & Leak repair requirements \\
\hline North Dakota & No additional requirements. & No additional requirements. \\
\hline Ohio & $\begin{array}{l}\text { Leaks must be classified as follows: } \\
\text { - Grade 1: A leak that presents an existing or probable } \\
\text { hazard to persons or property and requires immediate } \\
\text { repair or continuous action until the conditions are no } \\
\text { longer hazardous. } \\
\text { - Grade 2: A leak that is recognized as being nonhazardous } \\
\text { at the time of detection, but requires scheduled repair } \\
\text { based upon the severity and/or location of the leak. } \\
\text { - Grade 3: A leak that is recognized as being nonhazardous } \\
\text { at the time of detection and can be reasonably expected to } \\
\text { remain non-hazardous. } \\
\text { A Grade } 1 \text { leak may be reclassified by performing physical } \\
\text { action to the pipeline. Venting, holes, aerators, or soil purging } \\
\text { of a leak are not considered physical actions to the pipeline. }\end{array}$ & $\begin{array}{l}\text { Class } 1 \text { leaks require immediate and continuous action. If a } \\
\text { Grade } 1 \text { leak is reclassified after performing a physical action, } \\
\text { the timeframe for any required repair(s) will be calculated from } \\
\text { the date of reclassification. } \\
\text { A Grade } 2 \text { leak must be repaired with } 15 \text { months from the date } \\
\text { of discovery, unless the pipeline is scheduled for replacement } \\
\text { within } 24 \text { months. If replacement is cancelled after the } 15^{\text {th }} \\
\text { month after discovery of the leak, the leak must be cleared } \\
\text { within } 45 \text { days. Grade } 2 \text { leaks must be reevaluated every } 6 \\
\text { months until cleared. } \\
\text { Grade } 3 \text { leaks must be reevaluated during the next scheduled } \\
\text { survey or within } 15 \text { months from the date of the last } \\
\text { inspection. } 168\end{array}$ \\
\hline Oklahoma & No additional requirements. & No additional requirements. \\
\hline Oregon & No additional requirements. & No additional requirements. \\
\hline Pennsylvania & No additional requirements. & No additional requirements. \\
\hline Rhode Island & No additional requirements. & No additional requirements. \\
\hline $\begin{array}{l}\text { South } \\
\text { Carolina }\end{array}$ & $\begin{array}{l}\text { Leaks must be classified as follows: } \\
\text { - Grade 1: A leak that represents an existing or probable } \\
\text { hazard to persons or property and requires immediate } \\
\text { repair or continuous action until the conditions are no } \\
\text { longer hazardous. } \\
\text { - Grade 2: A leak that is recognized as being nonhazardous } \\
\text { at the time of detection but requires scheduled repair based } \\
\text { on probable future hazard. }\end{array}$ & $\begin{array}{l}\text { Pipeline operators must establish procedures for repairing leaks. } \\
\text { The procedures must provide for immediate repair of all Grade } 1 \\
\text { leaks. }{ }^{169}\end{array}$ \\
\hline
\end{tabular}

39 | Safety First, Environment Last | September 2015 


\begin{tabular}{|c|c|c|}
\hline Jurisdiction & Leak classification requirements & Leak repair requirements \\
\hline & $\begin{array}{l}\text { - Grade 3: A leak that is nonhazardous at the time of } \\
\text { detection and can reasonably be expected to remain } \\
\text { nonhazardous. }\end{array}$ & \\
\hline South Dakota & No additional requirements. & No additional requirements. \\
\hline Tennessee & $\begin{array}{l}\text { Leaks must be classified as follows: } \\
\text { - Grade 1: A gas leak which, due to its location and/or } \\
\text { relative magnitude, constitutes a potentially hazardous } \\
\text { condition to the public or buildings. } \\
\text { - Grade 2: A leak that does not constitute an immediate } \\
\text { hazardous condition to the public or buildings, but shall be } \\
\text { of a nature requiring scheduled repair. } \\
\text { - Grade 3: any other leak not classified as a Grade } 1 \text { or } 2 \\
\text { leak. }\end{array}$ & $\begin{array}{l}\text { Class } 1 \text { leaks require prompt corrective action. This action shall } \\
\text { consist of immediate effort to protect life and property and } \\
\text { continuous action until the condition is no longer hazardous and } \\
\text { scheduled for immediate repair. } \\
\text { Grade } 2 \text { leaks must be scheduled for repair within } 12 \text { months } \\
\text { and rechecked during the next annual survey. Rechecked leaks } \\
\text { that have not deteriorated may be rescheduled for repair if not } \\
\text { in a hazardous location and the repair would be difficult or } \\
\text { hazardous. } \\
\text { Grade } 3 \text { leaks must be reevaluated during the next survey. }{ }^{170}\end{array}$ \\
\hline Texas & $\begin{array}{l}\text { Leaks must be classified as follows: } \\
\text { - Grade 1: A leak that is an existing or probable hazard to } \\
\text { persons or property and requires the pipeline operator to } \\
\text { take action immediately to eliminate the hazard and make } \\
\text { repairs. } \\
\text { - Grade 2: A leak that is non-hazardous at the time of } \\
\text { detection, but requires the operator to schedule repair } \\
\text { based on probable future hazard. } \\
\text { - Grade 3: A leak that is non-hazardous at the time of } \\
\text { detection and reasonably can be expected to remain non- } \\
\text { hazardous. }\end{array}$ & $\begin{array}{l}\text { Grade } 1 \text { leaks require prompt corrective action. This may } \\
\text { include implementing an emergency plan, evacuating premises, } \\
\text { blocking off an area, rerouting traffic, eliminating sources of } \\
\text { ignition, venting the area, stopping the flow of gas, or notifying } \\
\text { emergency responders. } \\
\text { Certain Grade } 2 \text { leaks must be repaired within } 6 \text { months. All } \\
\text { Grade } 2 \text { leaks must be reevaluated every } 30 \text { days until repaired. } \\
\text { Grade } 3 \text { leaks must be repaired within } 36 \text { months. Those leaks } \\
\text { must be reevaluated during the next survey or within } 15 \text { months } \\
\text { of the date reported (whichever occurs first) until repaired. } \\
\text { When a leak is upgraded, the time period for repair is the } \\
\text { remaining time based on its original classification or the time } \\
\text { allowed for repair under its new grade (whichever is less). } \\
\text { However, this requirement does not apply to leaks that were } \\
\text { initially classified at a lower grade pending further, more } \\
\text { complete investigation. }{ }^{171}\end{array}$ \\
\hline
\end{tabular}

40 | Safety First, Environment Last | September 2015 


\begin{tabular}{|c|c|c|}
\hline Jurisdiction & Leak classification requirements & Leak repair requirements \\
\hline Utah & No additional requirements. & No additional requirements. \\
\hline Vermont & No additional requirements. & No additional requirements. \\
\hline Virginia & No additional requirements. & No additional requirements. \\
\hline Washington & $\begin{array}{l}\text { Leaks must be classified as follows: } \\
\text { - Grade 1: A leak that represents an existing or probable } \\
\text { hazard to persons or property and requires prompt action, } \\
\text { immediate repair, or continuous action until no longer } \\
\text { hazardous. } \\
\text { - Grade 2: A leak that is recognized as being not hazardous } \\
\text { at the time of detection but justifies scheduled repair based } \\
\text { on the potential for creating a future hazard. } \\
\text { - Grade } 3: \text { A leak that is not hazardous at the time of } \\
\text { detection and can reasonably be expected to remain so. } \\
\text { Classification must be based on an evaluation of the location } \\
\text { and/or magnitude of the leak. } \\
\text { Grade } 1 \text { and } 2 \text { leaks can be downgraded to Grade } 3 \text { once } \\
\text { without physical repair. }\end{array}$ & $\begin{array}{l}\text { Class } 1 \text { leaks require prompt corrective action. This may include } \\
\text { implementing an emergency plan, evacuating buildings, blocking } \\
\text { off an area, rerouting traffic, eliminating sources of ignition, } \\
\text { venting the area, stopping the flow of gas, or notifying } \\
\text { emergency responders. } \\
\text { Grade } 2 \text { leaks must be repaired within } 15 \text { months. If the } \\
\text { pipeline is under consideration for replacement, an additional } 6 \\
\text { months may be added to the maximum time for repair. Grade } 2 \\
\text { leaks must be reevaluated every } 6 \text { months until cleared. } \\
\text { Grade } 3 \text { leaks should be reevaluated during the next survey or } \\
\text { within } 15 \text { months of the reporting date (whichever is earlier), } \\
\text { until the leak is repaired or no longer results in a reading. } \\
\text { Where a leak is downgraded, the maximum timeframe for report } \\
\text { of the leak is } 21 \text { months. }{ }^{172}\end{array}$ \\
\hline West Virginia & No additional requirements. & No additional requirements. \\
\hline Wisconsin & No additional requirements. & No additional requirements. \\
\hline Wyoming & No additional requirements. & No additional requirements. \\
\hline
\end{tabular}

41 | Safety First, Environment Last | September 2015 


\section{Appendix 3: State leak reporting requirements}

The table below outlines additional requirements, in excess of the minimum federal standards, for leak reporting in each state.

\begin{tabular}{|c|c|c|}
\hline Jurisdiction & One-off (incident) reporting requirements & Periodic (aggregate) reporting requirements \\
\hline Alabama & $\begin{array}{l}\text { A pipeline operator must report, to the Public Service Commission, } \\
\text { any incident reportable to the PHMSA. Other incidents, resulting in } \\
\text { property damage exceeding } \$ 5,000 \text {, must also be reported. }\end{array}$ & $\begin{array}{l}\text { A pipeline operator must file, with the Public Service } \\
\text { Commission, a copy of any annual report filed with } \\
\text { PHMSA. }{ }^{773}\end{array}$ \\
\hline Alaska & No state pipeline safety regulations. & \\
\hline Arizona & $\begin{array}{l}\text { A pipeline operator must file, with the Arizona Corporation } \\
\text { Commission's Office of Pipeline Safety, a report on incidents involving: } \\
\text { - the release of gas resulting in an individual losing consciousness, } \\
\text { an unintentional fire or explosion, or property damage exceeding } \\
\$ 25,000 \text { (including the cost of lost gas); } \\
\text { - any unintentional release of gas from a transmission pipeline; } \\
\text { - emergency shutdown of a transmission pipeline; } \\
\text { - evacuation, outage, or property damage and resulting expenses } \\
\text { exceeding } \$ 25,000 \text { (including the cost of lost gas); or } \\
\text { - overpressure of certain pipeline systems. }\end{array}$ & $\begin{array}{l}\text { A pipeline operator must file, with the Office of Pipeline } \\
\text { Safety, an annual report using the forms required for } \\
\text { annual reporting to PHMSA. }{ }^{174}\end{array}$ \\
\hline Arkansas & $\begin{array}{l}\text { A pipeline operator must report, to the Arkansas Public Service } \\
\text { Commission's Pipeline Safety Office, any incident reportable to the } \\
\text { PHMSA. Other incidents, resulting in personal injury requiring out- } \\
\text { patient treatment and/or property damage totaling } \$ 5,000 \text { (including } \\
\text { the cost of lost gas), must also be reported. }\end{array}$ & $\begin{array}{l}\text { A pipeline operator must file, with the Pipeline Safety } \\
\text { Office, a copy of any annual report filed with the PHMSA. } \\
\text { A distribution pipeline operator must file, with the Office } \\
\text { of Pipeline Safety, a leak report semiannually. The report } \\
\text { must identify and describe the state of each leak broken } \\
\text { down as follows: leaks known to exist at the start of the } \\
6 \text { month period; leaks detected during the } 6 \text { month } \\
\text { period; and leaks repaired during the period. } \\
\text { Specified data must be provided about each leak, } \\
\text { including date and method of discovery, location, cause, } \\
\text { and repair. }{ }^{175}\end{array}$ \\
\hline
\end{tabular}

42 | Safety First, Environment Last | September 2015 


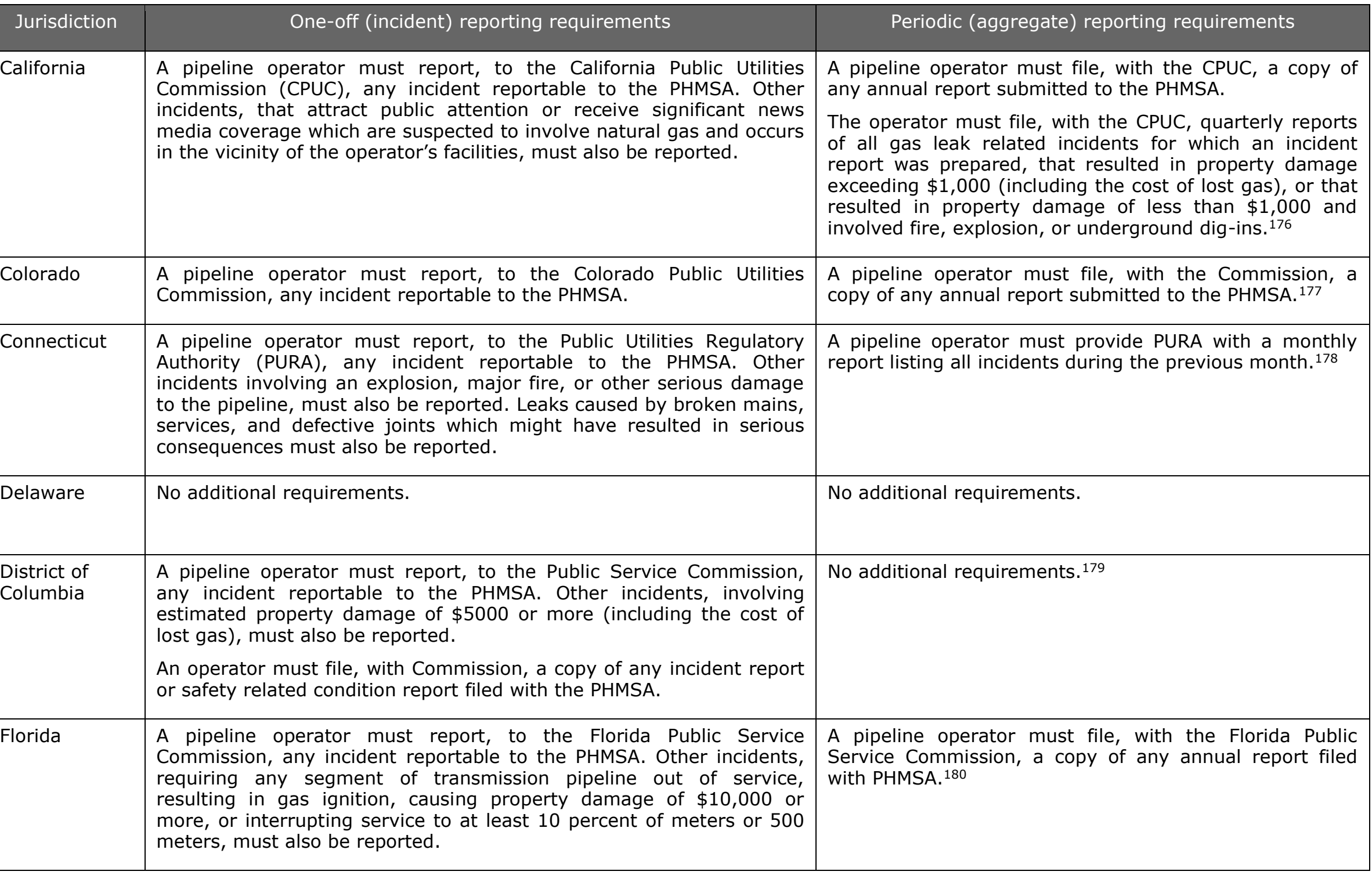

43 | Safety First, Environment Last | September 2015 


\begin{tabular}{|c|c|c|}
\hline Jurisdiction & One-off (incident) reporting requirements & Periodic (aggregate) reporting requirements \\
\hline Georgia & $\begin{array}{l}\text { A pipeline operator must report, to the Georgia Public Service } \\
\text { Commission, any incident reportable to the PHMSA. }\end{array}$ & No additional requirements. ${ }^{181}$ \\
\hline daho & $\begin{array}{l}\text { A pipeline operator must report, to the Idaho Public Utilities } \\
\text { Commission, any incident reportable to the PHMSA. Other incidents, } \\
\text { resulting in serious damage or service interruption, must also be } \\
\text { reported. }\end{array}$ & No additional requirements. ${ }^{182}$ \\
\hline [llinois & $\begin{array}{l}\text { A pipeline operator must report, to the Illinois Commerce Commission } \\
\text { (ICC), any incident reportable to the PHMSA. }\end{array}$ & $\begin{array}{l}\text { A pipeline operator must file, with the ICC, a copy of any } \\
\text { annual report filed with PHMSA. }{ }^{183}\end{array}$ \\
\hline ndiana & $\begin{array}{l}\text { A pipeline operator must report, to the Indiana Utility Regulatory } \\
\text { Commission (IURC), any incident reportable to the PHMSA. }\end{array}$ & $\begin{array}{l}\text { A pipeline operator must file, with the IURC, a copy of } \\
\text { any annual report filed with PHMSA. }{ }^{184}\end{array}$ \\
\hline owa & $\begin{array}{l}\text { A pipeline operator must report, to the Iowa Utilities Board (IUB), any } \\
\text { incident reportable to the PHMSA. Other incidents, involving the } \\
\text { release of gas resulting in estimated property damage of } \$ 15,000 \text { or } \\
\text { more (including the cost of lost gas) or interruption of service to } 50 \text { or } \\
\text { more customers, must also be reported. }\end{array}$ & $\begin{array}{l}\text { A pipeline operator must file, with the IUB, a copy of any } \\
\text { annual report filed with PHMSA. } \\
\text { An operator must compile a monthly record of gas } \\
\text { service specifying, among other things, progress on leak } \\
\text { survey programs including the number of leaks found } \\
\text { and, if known, the cause and type of pipe involved. }{ }^{185}\end{array}$ \\
\hline Kansas & $\begin{array}{l}\text { A pipeline operator must file, with the Kansas Corporation Commission } \\
\text { (KCC), a copy of any incident report filed with PHMSA. }\end{array}$ & $\begin{array}{l}\text { A pipeline operator must file, with the KCC, a copy of any } \\
\text { annual report filed with PHMSA. }{ }^{886}\end{array}$ \\
\hline Kentucky & $\begin{array}{l}\text { A pipeline operator must report, to the Kentucky Public Service } \\
\text { Commission (KPSC), any incident reportable to the PHMSA. The } \\
\text { operator must also report other incidents: } \\
\text { - requiring a segment of pipeline to be removed from service; } \\
\text { - resulting in gas ignition; } \\
\text { - causing estimated property of } \$ 25,000 \text { or more; } \\
\text { - resulting in loss of service to at least } 40 \text { customers for at least } 4\end{array}$ & $\begin{array}{l}\text { A pipeline operator must file, with the KPSC, a copy of } \\
\text { any annual report filed with PHMSA. }{ }^{187}\end{array}$ \\
\hline
\end{tabular}

44 | Safety First, Environment Last | September 2015 


\begin{tabular}{|c|c|c|}
\hline Jurisdiction & One-off (incident) reporting requirements & Periodic (aggregate) reporting requirements \\
\hline & $\begin{array}{l}\text { hours; } \\
\text { - causing the loss of a sizable amount of gas; or } \\
\text { - receiving extensive news coverage. }\end{array}$ & \\
\hline Louisiana & $\begin{array}{l}\text { A pipeline operator must file, with the Louisiana Department of } \\
\text { Natural Resources, a copy of any incident report filed with PHMSA. }\end{array}$ & $\begin{array}{l}\text { A pipeline operator must file, with the Department of } \\
\text { Natural Resources, a copy of any annual report filed with } \\
\text { PHMSA. }\end{array}$ \\
\hline Maine & $\begin{array}{l}\text { A pipeline operator must report, to the Maine Public Utilities } \\
\text { Commission, any incident reportable to the PHMSA. Other incidents, } \\
\text { resulting in more than } 7 \text { days' lost work time for an employee or } \\
\text { independent contractor, must also be reported. }\end{array}$ & $\begin{array}{l}\text { A pipeline operator must file an annual report showing } \\
\text { the number of leaks per mile by pipe material. } \\
\text { An operator must file monthly leak reports describing the } \\
\text { status and classification of leaks as follows: } \\
\text { - leaks at the beginning of each month; } \\
\text { - leaks reported during the month; } \\
\text { - leaks repaired during the month; and } \\
\text { - leaks awaiting repair at the end of the month. }{ }^{189}\end{array}$ \\
\hline Maryland & $\begin{array}{l}\text { A pipeline operator must file, with the Public Service Commission of } \\
\text { Maryland, a copy of any incident report filed with PHMSA. }\end{array}$ & $\begin{array}{l}\text { A pipeline operator must file, with the Public Service } \\
\text { Commission, a copy of any annual report filed with } \\
\text { PHMSA. }{ }^{190}\end{array}$ \\
\hline Massachusetts & No additional state rules. & $\begin{array}{l}\text { A pipeline operator must file an annual return } \\
\text { documenting the number of leaks in mains, the number } \\
\text { of leaks per mile, and the cost of repairs per mile of pipe. } \\
\text { A distribution pipeline operator must file an annual report } \\
\text { specifying, among other things, the location of leak } \\
\text { existing as of the date of the report, the date each leak } \\
\text { was classified, and the dates of repair performed on each } \\
\text { leak. }{ }^{191}\end{array}$ \\
\hline
\end{tabular}

45 | Safety First, Environment Last | September 2015 


\begin{tabular}{|c|c|c|}
\hline Jurisdiction & One-off (incident) reporting requirements & Periodic (aggregate) reporting requirements \\
\hline Michigan & $\begin{array}{l}\text { A pipeline operator must report, to the Michigan Public Service } \\
\text { Commission, any incident reportable to the PHMSA. The operator } \\
\text { must also report other incidents: } \\
\text { - resulting in property damage of } \$ 10,000 \text { or more affecting pipeline } \\
\text { system operations, regardless of whether there was a release of } \\
\text { gas; } \\
\text { - resulting in the loss of service to more than } 100 \text { customers; } \\
\text { - involving a customer's gas facility that results in a fatality or } \\
\text { explosion causing structural damage; or } \\
\text { - receiving or likely to receive extensive news coverage. }\end{array}$ & $\begin{array}{l}\text { A pipeline operator must file, with the Michigan Public } \\
\text { Service Commission, a copy of any annual report filed } \\
\text { with PHMSA. }{ }^{192}\end{array}$ \\
\hline Minnesota & $\begin{array}{l}\text { A pipeline operator must report, to the Department of Public Safety, } \\
\text { any incident reportable to the PHMSA. The operator must also report } \\
\text { other incidents involving a release of gas resulting in: } \\
\text { - the evacuation of } 10 \text { or more people or a school, hospital, or health } \\
\text { care facility; } \\
\text { - the rerouting of traffic or closing of a highway; } \\
\text { - an outage affecting } 50 \text { or more customers; } \\
\text { - any media attention; or } \\
\text { - unintentional fire or explosion. } \\
\text { Any gas leak caused by excavation must also be reported. }\end{array}$ & No additional requirements. ${ }^{193}$ \\
\hline Mississippi & No additional requirements. & No additional requirements. \\
\hline Missouri & $\begin{array}{l}\text { A pipeline operator must report, to the Public Service Commission } \\
\text { (PSC), any incident reportable to the PHMSA. Other incidents, } \\
\text { involving a release of gas resulting in personal injury involving } \\
\text { medical care administered in an emergency room or health care } \\
\text { facility or property damage of } \$ 10,000 \text { or more (including the cost of } \\
\text { lost gas), must also be reported. An operator must also file, with the } \\
\text { PSC, a copy of any safety-related condition report filed with PHMSA. }\end{array}$ & $\begin{array}{l}\text { A pipeline operator must file, with the Public Service } \\
\text { Commission, a copy of any annual report filed with } \\
\text { PHMSA. }{ }^{194}\end{array}$ \\
\hline
\end{tabular}

46 | Safety First, Environment Last | September 2015 


\begin{tabular}{|c|c|c|}
\hline Jurisdiction & One-off (incident) reporting requirements & Periodic (aggregate) reporting requirements \\
\hline Montana & No additional requirements. & No additional requirements. \\
\hline Nebraska & $\begin{array}{l}\text { A pipeline operator must report, to the State Fire Marshall, any } \\
\text { incident reportable to the PHMSA. Other incidents, involving failure } \\
\text { which results in the explosion or ignition of natural gas, must also be } \\
\text { reported. } \\
\text { An operator must file, with the State Fire Marshall, a copy of any } \\
\text { incident report or safety-related condition report filed with PHMSA. }\end{array}$ & $\begin{array}{l}\text { A pipeline operator must file, with the State Fire Marshall, } \\
\text { a copy of any annual report filed with the PHMSA. }{ }^{195}\end{array}$ \\
\hline Nevada & $\begin{array}{l}\text { A pipeline operator must report, to the Public Utilities Commission, } \\
\text { any incident reportable to the PHMSA. The operator must also report } \\
\text { other incidents involving: } \\
\text { - the release of gas from a pipeline resulting in an evacuation; } \\
\text { - damage to a pipeline requiring an immediate pressure reduction, } \\
\text { repair, or replacement; or } \\
\text { - any exceedance of the maximum allowance operating pressure. } \\
\text { An operator must file, with the Commission, a copy of any incident } \\
\text { report or safety-related condition report filed with PHMSA. }\end{array}$ & $\begin{array}{l}\text { A pipeline operator must file, with the Public Utilities } \\
\text { Commission, a copy of any annual report filed with the } \\
\text { PHMSA. }{ }^{196}\end{array}$ \\
\hline $\begin{array}{l}\text { New } \\
\text { Hampshire }\end{array}$ & $\begin{array}{l}\text { A pipeline operator must report, to the Public Utilities Commission } \\
\text { (PUC), any incident reportable to the PHMSA. The operator must also } \\
\text { report other incidents involving: } \\
\text { - the release of gas from a pipeline that results in estimated property } \\
\text { damage of } \$ 5,000 \text { or more; } \\
\text { - a fire or explosion at a liquefied natural gas facility; } \\
\text { - an evacuation of a building because of the presence of gas; } \\
\text { - an unplanned service interruption or outage resulting in at least } 50 \\
\text { customer outage hours or an outage at a state, federal, or } \\
\text { municipal facility, hospital, school, or other facility; } \\
\text { - a security breach or threat jeopardizing operation of a major } \\
\text { facility; }\end{array}$ & $\begin{array}{l}\text { A pipeline operator must report, to the PUC, the status of } \\
\text { any leaks occurring in its system each month. The report } \\
\text { must provide a description of each leak, classified by } \\
\text { type, as follows: } \\
\text { - leaks as of the beginning of each months; } \\
\text { - leaks reported during the month; } \\
\text { - leaks repaired during the month; and } \\
\text { - leaks reported and awaiting repair at the end of the } \\
\text { month. } \\
\text { Specified data must be provided about each leak } \\
\text { reported during the month, the address of the leak, leak } \\
\text { area, leak classification, pipeline facility, and operating }\end{array}$ \\
\hline
\end{tabular}

47 | Safety First, Environment Last | September 2015 


\begin{tabular}{|c|c|c|}
\hline Jurisdiction & One-off (incident) reporting requirements & Periodic (aggregate) reporting requirements \\
\hline & $\begin{array}{l}\text { - any exceedance of the maximum allowable operating pressure; } \\
\text { - an event that is or will be reported in the news media; } \\
\text { - inadequate odorization of gas. } \\
\text { An operator must file, with the PUC, a copy of any incident report filed } \\
\text { with PHMSA. Reports must also be filed on certain other incidents. }\end{array}$ & pressure. ${ }^{197}$ \\
\hline New Jersey & $\begin{array}{l}\text { A pipeline operator must report, to the Board of Public Utilities, any } \\
\text { incident reportable to the PHMSA. The operator must also report on } \\
\text { other incidents resulting in: } \\
\text { - serious disabling or incapacitating injuries to persons; } \\
\text { - damage to the property of the utility materially affecting its service } \\
; \\
\text { - damage to the property of others exceeding } \$ 5,000 \text {; or } \\
\text { - accidental ignition of gas. } \\
\text { An operator must file, with the Board of Public Utilities, a copy of any } \\
\text { incident report or safety related condition report filed with PHMSA. }\end{array}$ & $\begin{array}{l}\text { A pipeline operator must report to the Board of Public } \\
\text { Utilities, on a quarterly basis, any leaks or other } \\
\text { conditions that may affect the safety or operation of the } \\
\text { pipeline. } \\
\text { Each pipeline operator must file, with the Board of Public } \\
\text { Utilities, an annual leak classification status report } \\
\text { indicating the number of open, unrepaired leaks by grade } \\
\text { classification. The operator must also file, with the Board } \\
\text { of Public Utilities, a copy of any annual report filed with } \\
\text { PHMSA. }{ }^{198}\end{array}$ \\
\hline New Mexico & $\begin{array}{l}\text { A pipeline operator must report, to the New Mexico Public Regulation } \\
\text { Commission (NMPRC), any incident reportable to PHMSA. The } \\
\text { operator must also report other incidents resulting in property } \\
\text { damage of } \$ 5,000 \text { or more (including the cost of lost gas). } \\
\text { An operator must file, with the NMPRC, a copy of any incident report } \\
\text { and safety-related condition report filed with PHMSA. }\end{array}$ & $\begin{array}{l}\text { Each pipeline operator must file, with the NMPRC, a copy } \\
\text { of any annual report filed with PHMSA. }{ }^{99}\end{array}$ \\
\hline New York & $\begin{array}{l}\text { A pipeline operator must report, to the New York State Public Service } \\
\text { Commission (NYPSC), any accidents involving gas facilities which } \\
\text { cause injury or death to any person or damage to property or could } \\
\text { cause concern because of news media coverage. } \\
\text { An operator must file, with the NYPSC, a copy of any incident report } \\
\text { or safety-related condition report filed with PHMSA. }\end{array}$ & $\begin{array}{l}\text { A pipeline operator must file, with the NYPSC, a copy of } \\
\text { any annual report filed with PHMSA. } \\
\text { A pipeline operator must submit, to the NYPSC, a } \\
\text { monthly analysis of its performance in responding to } \\
\text { reports of gas leaks and other emergencies. }{ }^{200}\end{array}$ \\
\hline
\end{tabular}

48 | Safety First, Environment Last | September 2015 


\begin{tabular}{|c|c|c|}
\hline Jurisdiction & One-off (incident) reporting requirements & Periodic (aggregate) reporting requirements \\
\hline North Carolina & $\begin{array}{l}\text { A pipeline operator must report, to the North Carolina Utilities } \\
\text { Commission (NCUC), any incident reportable to the PHMSA. Other } \\
\text { incidents, involving the release of gas resulting in property damage of } \\
\$ 5,000 \text { or more (including the cost of lost gas), must also be reported. } \\
\text { An operator must file, with the NCUC, two copies of each incident } \\
\text { report and safety-related condition report filed with the PHMSA. }\end{array}$ & $\begin{array}{l}\text { A pipeline operator must file, with the NCUC, two copies } \\
\text { of any annual report filed with PHMSA. }{ }^{201}\end{array}$ \\
\hline North Dakota & No additional requirements. & No additional requirements. \\
\hline Ohio & $\begin{array}{l}\text { A pipeline operator must report, to the Ohio Public Utilities } \\
\text { Commission (OPUC), any incident reportable to the PHMSA. Other } \\
\text { incidents, resulting in the interruption of service to } 100 \text { or more } \\
\text { customers for a period of } 2 \text { hours or more, must also be reported. } \\
\text { An operator must file, with the OPUC, a copy of any incident report or } \\
\text { safety-related condition report filed with PHMSA. }\end{array}$ & $\begin{array}{l}\text { A pipeline operator must file, with the OPUC, a copy of } \\
\text { any annual report filed with PHMSA. } \\
\text { A pipeline operator, except the operator of a master } \\
\text { meter system, must submit an annual report of incidents } \\
\text { and service failures to the OPUC. }{ }^{202}\end{array}$ \\
\hline Oklahoma & $\begin{array}{l}\text { A pipeline operator must report, to the Oklahoma Corporation } \\
\text { Commission (OCC), any incident reportable to the PHMSA. The } \\
\text { operator must also report other incidents involving a release of gas } \\
\text { resulting in estimated property damage of } \$ 5,000 \text { or more (including } \\
\text { the cost of lost gas), property damage causing a loss of service to } \\
\text { over } 50 \text { customers for } 2 \text { hours, and certain gas leaks resulting in the } \\
\text { evacuation of a building. } \\
\text { An operator must file, with the OCC, a copy of any incident report and } \\
\text { safety-related condition report filed with PHMSA. }\end{array}$ & $\begin{array}{l}\text { A pipeline operator must file, with the OCC, a copy of any } \\
\text { annual report filed with PHMSA. }{ }^{203}\end{array}$ \\
\hline Oregon & $\begin{array}{l}\text { A pipeline operator must report, to the Public Utility Commission, any } \\
\text { incident reportable to the PHMSA. Other incidents, resulting in } \\
\text { damage to the operator's property exceeding } \$ 5,000 \text {, must also be } \\
\text { reported. }\end{array}$ & No additional requirements. ${ }^{204}$ \\
\hline Pennsylvania & $\begin{array}{l}\text { A pipeline operator must report, to the Public Utility Commission, any } \\
\text { incident reportable to the PHMSA. Other incidents of an unusual } \\
\text { nature involving a physical or cyber-attack causing interruption of } \\
\text { service and/or over } \$ 50,000 \text { in damages must also be reported. }\end{array}$ & No additional requirements. ${ }^{205}$ \\
\hline
\end{tabular}

49 | Safety First, Environment Last | September 2015 


\begin{tabular}{|c|c|c|}
\hline Jurisdiction & One-off (incident) reporting requirements & Periodic (aggregate) reporting requirements \\
\hline Rhode Island & $\begin{array}{l}\text { A pipeline operator must report, to the Rhode Island Public Utilities } \\
\text { Commission, any incident resulting: } \\
\text { - in an unanticipated release of gas from a pipeline or LNG facility or } \\
\text { causing a death, personal injury, or property damage } \\
\text { - from the excavating operations of another party; } \\
\text { - in the emergency shutdown of an LNG facility; } \\
\text { - in the involvement by police, fire, or media personnel; } \\
\text { - in a house or building being evacuated; and } \\
\text { - any other situation that is significant in the opinion of the operator. }\end{array}$ & No additional requirements. ${ }^{206}$ \\
\hline $\begin{array}{l}\text { South } \\
\text { Carolina }\end{array}$ & $\begin{array}{l}\text { A pipeline operator must report, to the Public Service Commission } \\
\text { (PSC), any incident reportable to the PHMSA. Other incidents, } \\
\text { resulting in property damage in excess of } \$ 5,000 \text { (including the cost } \\
\text { of lost gas), must also be reported. } \\
\text { An operator must file, with the PSC, a copy of any incident report and } \\
\text { safety related condition report filed with PHMSA. }\end{array}$ & $\begin{array}{l}\text { A pipeline operator must file, with the PSC, a copy of any } \\
\text { annual report filed with PHMSA. }{ }^{207}\end{array}$ \\
\hline South Dakota & No additional requirements. & No additional requirements. \\
\hline Tennessee & $\begin{array}{l}\text { A pipeline operator must report, to the Tennessee Regulatory } \\
\text { Authority, any accident resulting in death or property damage. Other } \\
\text { incidents, resulting in interruption of service to a major portion of the } \\
\text { distribution system, must also be reported. }\end{array}$ & No additional requirements. ${ }^{208}$ \\
\hline Texas & $\begin{array}{l}\text { A pipeline operator must report, to the Texas Railroad Commission } \\
\text { (RRC), any incident reportable to the PHMSA. } \\
\text { A pipeline operator must submit, to the RRC, a written report on any } \\
\text { safety-related condition required to be reported to PHMSA. }\end{array}$ & $\begin{array}{l}\text { The operator of a distribution system or plastic } \\
\text { transmission line must submit, to the RRC, a leak report } \\
\text { semi-annually. The report must list all leaks on pipeline } \\
\text { facilities. For each leak, the report must specify the leak } \\
\text { location and classification, facility type, pipe type and } \\
\text { size, leak cause, and repair method. } \\
\text { A pipeline operator must submit an annual report in the } \\
\text { same manner as required by the federal regulations. }{ }^{209}\end{array}$ \\
\hline
\end{tabular}

50 | Safety First, Environment Last | September 2015 


\begin{tabular}{|c|c|c|}
\hline Jurisdiction & One-off (incident) reporting requirements & Periodic (aggregate) reporting requirements \\
\hline Utah & $\begin{array}{l}\text { A pipeline operator must file, with the Utah Division of Public Utilities } \\
\text { (UDPU), a copy of any incident report filed with PHMSA. }\end{array}$ & $\begin{array}{l}\text { A pipeline operator must file, with the UDPU, an annual } \\
\text { report in the same form as filed with PHMSA. }{ }^{210}\end{array}$ \\
\hline Vermont & $\begin{array}{l}\text { A pipeline operator must report, to the Vermont Public Service Board, } \\
\text { any incident reportable to the PHMSA. Other incidents, causing } \\
\text { damage to property in excess of } \$ 5,000 \text {, must also be reported. }\end{array}$ & No additional requirements. ${ }^{211}$ \\
\hline Virginia & No additional requirements. & No additional requirements. \\
\hline Washington & $\begin{array}{l}\text { A pipeline operator must report, to the Washington Utilities and } \\
\text { Transportation Commission, any incident reportable to the PHMSA. } \\
\text { The operator must also report other incidents resulting in: } \\
\text { - evacuation of a building or high occupancy structure or area; } \\
\text { - unintentional ignition of gas; } \\
\text { - unscheduled interruption of service to } 25 \text { or more customers; } \\
\text { - exceedance of the maximum allowance operating pressure. } \\
\text { The operator must also report any condition resulting in: } \\
\text { - the uncontrolled release of gas for more than } 2 \text { hours; } \\
\text { - the taking of a high pressure supply or transmission pipeline or a } \\
\text { - gajor distribution pipeline out of service; } \\
\text { - gas pipeline pressure dropping below safe operating conditions; }\end{array}$ & $\begin{array}{l}\text { A pipeline operator must file, with the Washington } \\
\text { Utilities and Transportation Commission, a copy of any } \\
\text { annual report filed with PHMSA.212 }\end{array}$ \\
\hline West Virginia & $\begin{array}{l}\text { A pipeline operator must report, to the Public Service Commission, } \\
\text { any incident that causes personal injury requiring hospitalization, } \\
\text { fatality, or estimated property damage of } \$ 50,000 \text { or more. }\end{array}$ & No additional requirements. ${ }^{213}$ \\
\hline
\end{tabular}

51 | Safety First, Environment Last | September 2015 


\begin{tabular}{|c|c|c|}
\hline Jurisdiction & One-off (incident) reporting requirements & Periodic (aggregate) reporting requirements \\
\hline Wisconsin & No additional requirements. & $\begin{array}{l}\text { A pipeline operator must file, with the Public Service } \\
\text { Commission, a copy of any annual report filed with } \\
\text { PHMSA. At the same of time as filing the annual report, } \\
\text { the operator must also report the number of leaks found } \\
\text { in customer-owned facilities during the preceding } \\
\text { calendar year. }{ }^{214}\end{array}$ \\
\hline Wyoming & $\begin{array}{l}\text { A pipeline operator must report, to the Public Service Commission, } \\
\text { any incident reportable to the PHMSA. Other incidents, resulting in a } \\
\text { service interruption causing loss of service to } 25 \text { gas meters or } \\
\text { customers or any evacuation that displaces } 25 \text { or more people, must } \\
\text { also be reported. }\end{array}$ & $\begin{array}{l}\text { A pipeline operator must file, with the Public Service } \\
\text { Commission, quarterly reports of all major, minor, and } \\
\text { sustained service interruptions. }{ }^{215}\end{array}$ \\
\hline
\end{tabular}




\section{- Endnotes -}

${ }^{1}$ U.S. Energy Information Administration, U.S. Dry Natural Gas Production, NATURAL Gas, http://www.eia.gov/dnav/ng/hist/n9070us2A.htm (last visited Jun. 12, 2015).

2 Zhongmin WANG ET AL., A Retrospective ReVIEW OF Shale Gas DeVELOPMENT IN THE UNITED STATES: WHAT LED TO THE BOOM? 1 (2013), available at http://www.rff.org/RFF/documents/RFF-DP-1312.pdf.

3 U.S. ENERGY INFORMATION ADMINISTRATION, ANNUAL ENERGY OUTLOOK 2015 WiTH PROJECTIONS TO 2030 A-28 (2015), available at http://www.eia.gov/forecasts/aeo/mt naturalgas.cfm.

4 U.S. Environmental Protection Agency, Coal, CLEAN ENERGY, http://www.epa.gov/cleanenergy/energyand-you/affect/coal.html (last updated Sep. 25, 2013) (indicating that "[w]hen coal is burned, carbon dioxide, nitrogen oxides, and mercury compounds are released"); U.S. Environmental Protection Agency, Natural Gas, ClEAN ENERGY, http://www.epa.gov/cleanenergy/energy-and-you/affect/natural-gas.html (last updated Sep. 25,2015 ) (finding that "[e]missions of sulfur dioxide and mercury compounds from burning natural gas are negligible").

5 U.S. Environmental Protection Agency, Natural Gas, ClEAN ENERGY, http://www.epa.gov/cleanenergy/energy-and-you/affect/natural-gas.html (last updated Sep. 25, 2015) (finding that "[a]t the power plan, the burning of natural gas produces nitrogen oxides and carbon dioxide, but in lower quantities than burning coal or oil').

6 U.S. Environmental Protection Agency, Natural Gas, CleAn EnERGy, http://www.epa.gov/cleanenergy/energy-and-you/affect/natural-gas.html (last updated Sep. 25, 2015) (estimating that natural gas-fired power plants emit 1,135 pounds of carbon dioxide and 1.7 pounds of nitrogen oxides per megawatt hour of electricity generated); U.S. Environmental Protection Agency, Coal, CLEAN ENERGY, http://www.epa.gov/cleanenergy/energy-and-you/affect/coal.html (last updated Sep. 25, 2013) (estimating that coal-fired power plants emit 2,249 pounds of carbon dioxide and 6 pounds of nitrogen oxides per megawatt hour of electricity generated); U.S. Environmental Protection Agency, Oil, CLEAN ENERGY, http://www.epa.gov/cleanenergy/energy-and-you/affect/oil.html (last updated Sep. 25, 2013) (estimating that oil-fired power plants emit 1,672 pounds of carbon dioxide and 4 pounds of nitrogen oxides per megawatt hour of electricity generated).

${ }^{7}$ Gunnar Myhre et al., Anthropogenic and Natural Radiative Forcing, in Climate Change 2013: The PHysiCAL SCIENCE BASIS: WORKING GROUP I CONTRIBUTION TO THE FIFTH ASSESSMENT REPORT OF THE Intergovernmental PANEL on Climate Change 659, 714 (Thomas F. Stocker et al. eds., 2013). 


\section{- Endnotes Continued -}

8 Ramón A. Alvarez et al., Greater focus needed on methane leakage from natural gas infrastructure, PROCEEDINGS OF THE NATIONAL ACADEMY OF SCIENCES 6435, 6437 (2012) (finding that switching from coal to natural gasfired electricity generation only benefits the climate if the rate of leakage is less than 3.2 percent). See also Steven Hamburg, Methane: A Key to Dealing with Carbon Pollution?, Energy Exchange (Nov. 5, 2013), http://blogs.edf.org/energyexchange/2013/11/05/methane-a-key-to-dealing-with-carbon-pollution/ (indicating that switching from coal to natural gas-fired electricity generation produces climate benefits if the rate of leakage is less than 2.7 percent). The Environmental Defense Fund has commissioned a series of studies aimed at measuring leaks from the natural gas system. Currently, there is no consensus on the percentage of natural gas that is lost through leaks.

9 The EPA defines "natural gas systems" as comprising all equipment used to produce, transport, store, and distribute natural gas. See U.S. ENVIRONMENTAL PROTECTION AGENCY, INVENTORY OF U.S. GREENHOUSE GAS EMISSIONS AND SINKS: 1990 - 2013 3-68 (2015), available at http://www.epa.gov/climatechange/ghgemissions/usinventoryreport.html.

${ }^{10}$ Id. at ES-5 - ES-7 (indicating that national methane emissions in 2013 totaled 636.6 million metric tons of carbon dioxide equivalent, of which 157.4 million metric tons was emitted by natural gas systems). Note however, recent studies suggesting that these figures may overstate methane emissions from natural gas production. See, for example, Brian K. Lamb et al., Direct Measurements Show Decreasing Methane Emissions from Natural Gas Local Distribution System in the United States, ENVIRON. SCI. AND TECH. 5161, 5167 (2015) (estimating that methane emissions from natural gas distribution systems are thirty-six to seventy percent lower than those reported in the greenhouse gas inventory); Daniel J. Zimmerle et al., Methane Emissions from the Natural Gas Transmission and Storage System in the United States, ENVIRON. SCI. AND TECH. (2015) (estimating that methane emissions from natural gas transmission and storage are twenty-seven percent lower than those reported in the greenhouse gas inventory).

11 Executive Office of the President, The President’s Climate ACtion Plan 10 (2013), available at https://www.whitehouse.gov/sites/default/ files/image/president27sclimateactionplan.pdf.

12 Press Release, White House, Fact Sheet: Administration Takes Steps Forward on Climate Action Plan by Announcing Actions to Cut Methane Emissions (Jan. 14, 2015), available at https://www.whitehouse.gov/thepress-office/2015/01/14/fact-sheet-administration-takes-steps-forward-climate-action-plan-anno-1.

13 Oil and Natural Gas Sector: Emissions Standards for New and Modified Sources (proposed Aug. 18, 2015) (to be codified at 40 CFR pt. 60). 


\section{- Endnotes Continued-}

14 Press Release, White House, Fact Sheet: Administration Takes Steps Forward on Climate Action Plan by Announcing Actions to Cut Methane Emissions (Jan. 14, 2015), available at https://www.whitehouse.gov/thepress-office/2015/01/14/fact-sheet-administration-takes-steps-forward-climate-action-plan-anno-1.

15 U.S. EnVIRONMENTAL Protection AgEnCy, supra note 9, at ES-5 - ES-7, 3-70 (estimating nationwide methane emissions at 636.3 million metric tons of carbon dioxide equivalent, methane emissions from natural gas systems at 157.4 million metric tons of carbon dioxide equivalent, and methane emissions from gas transportation and storage at 87.7 million metric tons of carbon dioxide equivalent).

16 Pipeline and Hazardous Materials Safety Administration, Gathering Line, PIPELINE GLOSSARY, http://primis.phmsa.dot.gov/comm/glossary/\#GatheringLine (last visited Jun. 12, 2015); Pipeline and Hazardous Materials Safety Administration, Transmission Line, PIPELINE Glossary, http://primis.phmsa.dot.gov/comm/glossary/\#TransmissionLine (last visited Jun. 12, 2015); Pipeline and Hazardous Materials Safety Administration, Distribution Line, PIPELINE GLOSSARY, http://primis.phmsa.dot.gov/comm/glossary/\#DistributionLine (last visited Jun. 12, 2015).

17 This study examines the regulation of natural gas transmission and distribution pipelines only. The regulation of gas gathering pipelines is not discussed.

18 Pipeline and Hazardous Materials Safety Administration, Gas Distribution Miles by Decade Installed, MILES BY

DECADE GAS DiSTRIBUTION, https://hip.phmsa.dot.gov/analyticsSOAP/saw.dll?PortalPages (last visited Jun. 12, 2015).

19 Pipeline and Hazardous Materials Safety Administration, Gas Transmission Miles by Decade Installed, MILES BY DECADE GAS TRANSMISSION,https://hip.phmsa.dot.gov/analyticsSOAP/saw.dll?PortalPages (last visited Jun. 12, 2015).

${ }^{20} I d$.

21 Pipeline and Hazardous Materials Safety Administration, Cast and Wrought Iron Inventory, PIPELINE REPLACEMENT UPDATES, http://opsweb.phmsa.dot.gov/pipeline replacement/cast iron inventory.asp (last visited Jun. 12, 2015).

$22 I d$.

23 Department of Transportation Pipeline and Hazardous Materials Safety Administration, Bare Steel Inventory, PIPELINE REPLACEMENT UPDATES, http://opsweb.phmsa.dot.gov/pipeline replacement/bare steel inventory.asp (last visited Jun. 12, 2015).

55 | Safety First, Environment Last | September 2015 


\section{- Endnotes Continued -}

24 U.S. Department of Transportation Pipeline and HaZardous Materials SaFety

Administration, White Paper on State Pipeline Infrastructure RePlacement Programs 4 (2011), available at http://opsweb.phmsa.dot.gov/pipelineforum/docs LPHMSA\%20111011-002\%20NARUC.pdf.

25 Pipeline Safety: Cast Iron Pipe (Supplementary Advisory Bulletin), 77 Fed. Reg. 17119 (March 23, 2013).

26 The Federal Energy Regulatory Commission is authorized, under section 1(b) of the Natural Gas Act (15

U.S.C. $\left.\int 717(\mathrm{~b})\right)$, to regulate the transportation and sale for resale of natural gas in interstate commerce. The Commission's regulatory authority includes, among other things, setting rates for the transportation of natural gas via interstate pipelines (i.e., pipelines crossing state boundaries).

27 Cost Recovery Mechanisms for Modernization of Natural Gas Facilities, 151 FERC $\mathbf{~ 6 1 , 0 4 7 ~ ( A p r . ~ 6 , ~ 2 0 1 5 ) . ~}$

28 State authorities set rates for the transportation of natural gas via intrastate pipelines. The authorities in twenty-seven states have approved programs allowing intrastate pipeline operators to recover the costs of replacing pipeline infrastructure. The twenty-seven states are Alabama, Arkansas, California, Colorado, Georgia, Illinois, Indiana, Kansas, Kentucky, Louisiana, Maryland, Massachusetts, Michigan, Mississippi, Missouri, Nebraska, New Hampshire, New Jersey, New York, Ohio, Oklahoma, Oregon, Rhode Island, South Carolina, Texas, Utah, and Virginia. See Pipeline and Hazardous Materials Safety Administration, Pipeline Safety Awareness, STATE REPLACEMENT PROGRAMS, http://opsweb.phmsa.dot.gov/pipelineforum/pipeline-materials/state-pipeline-system/state-replacementprograms/ (last visited May 14, 2015).

29 PricewaterhouseCoopers llP, Beyond Compliance: Creating a NeW Norm in Gas Pipeline LEAK MANAGEMENT 3 (2014), available at http://www.pwc.com/en US/us/power-andutilities/publications/assets/beyond-compliance-gas-pipeline-leak-management-pwc.pdf.

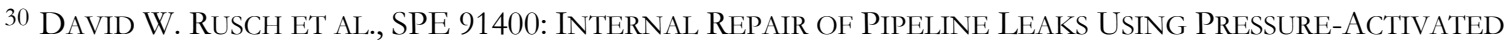
SEALANT: SPE 1-2 (2014), available at http://www.seal-tite.com/files/articles/SPE91400-1.pdf.

31 Id.

32 See, for example, Environmental Defense Fund, Boston: Snapshot of Natural Gas Leaks, ClimATE AND ENERGY, https://www.edf.org/climate/methanemaps/city-snapshots/boston (last visited Sep. 18, 2015).

33 NASDAQ, U.S. National Average Natural Gas Price, NATURAL Gas, http://www.nasdaq.com/markets/natural-gas.aspx?timeframe=1y (last visited Sep. 18, 2015). 


\section{- Endnotes Continued -}

34 National Transportation Safety Board, Gas Explosion and Subsequent Fire, ACCIDENT INVESTIGATIONS, http://www.ntsb.gov/investigations/AccidentReports/Pages/DCA14MP002 preliminary.aspx (last visited Jun. 12, 2015).

35 National Transportation Safety Board, Pacific Gas and Electric Company Natural Gas Transmission Pipeline Rupture and Fire, ACCident InVESTigations, http://www.ntsb.gov/investigations/Pages/2010 sanbruno ca.aspx (last visited Jun. 12, 2015).

${ }^{36}$ National Transportation Safety Board, Natural Gas Service Line Break and Subsequent Explosion and Fire, ACCIDENT InVESTIGATIONS, http://www.ntsb.gov/investigations/AccidentReports/Pages/PAB0701.aspx (last visited Jun. 12, 2015).

${ }^{37}$ National Transportation Safety Board, UGI Utilities, Inc., Natural Gas Distribution Pipeline Explosion and Fire, ACCIDENT INVESTIGATIONS, http://www.ntsb.gov/investigations/AccidentReports/Pages/PAR9601.aspx (last visited Jun. 12, 2015).

3849 U.S.C. $\$ 60105,60106$ (2015).

39 Alaska and Hawaii have not adopted their own pipeline safety rules. All other states have rules with respect to pipeline safety. In North Dakota and South Dakota, the state rules must be no more stringent than the minimum federal regulations. In Oklahoma, only certain state rules governing reporting may be more stringent than the minimum federal regulations. See National Association of Pipeline SAfETy Representatives, Compendium of State Pipeline SAfety Requirements \& Initiatives Providing InCREASEd Public SAFETy LeVELS COMPARED to CODE OF FEDERAL REgulations 33, 98, 244, 249, 270 (2013), available at http://www.naruc.org/Publications/Compendium\%20NAPSR\%20Second\%20Edition100313.pdf.

40 Pipeline safety regulations are enforced by state regulators in the contiguous U.S.

4149 U.S.C. $\$ 60102(b)(1)(B)(2015)$.

42 Press Release, Press Release, White House, supra note 12.

43 U.S. Department of Transportation, Guidance Manual for Operators of Small Natural Gas SYSTEMS IV-1 (2002), available at http://phmsa.dot.gov/portal/site/PHMSA/menuitem.6f23687cf7b00b0f22e $\underline{4 c 6962 \mathrm{~d} 9 \mathrm{c} 8789 / \text { ?vgnextoid }=\mathrm{a} 7 \mathrm{c} 6 \mathrm{ca} 170 \mathrm{a} 574110 \mathrm{VgnVCM} 1000009 \mathrm{ed} 07898 \mathrm{RCRD} \& v \text { gnextchannel }=67027 \mathrm{e} 2 \mathrm{~cd} 4}$ $4 \mathrm{~d} 3110 \mathrm{VgnVCM} 1000009 \mathrm{ed07898RCRD \& vgnextfmt=print \# page5}$ (indicating that, where there is gas leakage, vegetation may improve or deteriorate, fungus may grow, and insects may concentrate).

${ }^{44}$ Id. at IV-2. 


\section{- Endnotes Continued -}

45 Yudaya Sivathanu, Technology Status Report on Natural Gas LEAK Detection in PiPELINEs:

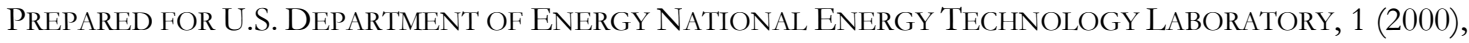
available at http://www.netl.doe.gov/File\%20Library/Research/Oil-

Gas/Natural\%20Gas/scanner technology 0104.pdf.

46 Pipeline and Hazardous Materials Safety Administration, Fact Sheet: Leak Detection Systems, PIPELINE SAFETY STAKEHOLDER COMMUNICATIONS (Dec. 1, 2011), https://primis.phmsa.dot.gov/comm/FactSheets/FSLeakDetectionsystems.htm.

47 SiVATHANU, supra note 45, at 1 (indicating that acoustic monitoring techniques are "unable to detect small leaks that do not produce acoustic emissions at levels substantially higher than the background noise level').

48 U.S. DEPARTMENT OF TRANSPORTATION, supra note 43, at IV-2 - IV-3.

49 SivATHANU, supra note 45 , at 3.

${ }^{50} I d$. at $3-4$.

51 U.S. Department of Transportation, Research and Special Programs Administration, OfFice OF Pipeline SAFEty, Guidance Manual for Operators of SMALl NATURAl Gas Systems V-1 (2002), available at http://phmsa.dot.gov/portal/site/PHMSA/menuitem.6f23687cf7b00b0f22e4c6962d9c8789/?vgne $\underline{\text { toid }=\text { a7c6ca170a574110VgnVCM1000009ed07898RCRD\&vgnextchannel }=67027 \mathrm{e} 2 \mathrm{~cd} 44 \mathrm{~d} 3110 \mathrm{VgnVCM} 1000}$ 009ed07898RCRD\&vgnextfmt=print. See also BIPARTISAN POLICY CENTER, NATURAL GAS INFRASTRUCTURE AND METHANE EMISSIONS 8 (2014), available at http://bipartisanpolicy. org/wpcontent/uploads/sites/default/files/BPC $\% 20$ Energy $\% 20$ Natural $\% 20$ Gas $\% 20$ Infrastructure $\% 20$ Methane $\% 20$ Emissions.pdf.

5249 CFR Part 192, Subpart M (2015) (setting out requirements for the maintenance of pipeline facilities).

5349 CFR SS 192.705(a), 192.721 (2015).

5449 CFR SS $192.706,192.723$ (2015).

5549 CFR SS 192.5(a)(1), (b)(1), 192.705(b), 192.706, 192.723 (2015).

56 Examples of a small outside area include a playground, recreation area, outdoor theatre, or other place of public assembly. See 49 CFR S 192.5(b)(3)(ii) (2015).

5749 CFR SS 192.5(a)(1), (b)(3), 192.705(b), 192.706 (2015). It should be noted that leakage surveys must be conducted on transmission lines carrying un-odorized gas twice per year, at intervals not exceeding 7.5 months.

58 | Safety First, Environment Last | September 2015 


\section{- Endnotes Continued -}

5849 CFR SS 192.5(a)(1), (b)(4), 192.705(b), 192.706 (2015). It should be noted that leakage surveys must be conducted on transmission lines carrying un-odorized gas four times per year, at intervals not exceeding 4.5 months.

59 Pipeline and Hazardous Materials Safety Administration, 668 PHMSA Terms, 49 CFR PARTS 192 AND 195 \& INSPECTOR WeB-BASED TRAINING TERMS, http://www.phmsa.dot.gov/staticfiles/PHMSA/Pipeline/TQ Glossary/Glossary.html (last visited Jun. 12, 2015).

60 The federal regulations only require pipeline operators to conduct patrols on distribution mains, not service lines. However, leakage surveys must be conducted on both distribution mains and service lines.

6149 CFR SS 192.721(b)(1), 192.723(b)(1) (2015).

62 The federal regulations only require pipeline operators to conduct patrols on distribution mains, not service lines. However, leakage surveys must be conducted on both distribution mains and service lines.

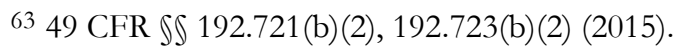

64 The states are Arizona, California, Florida, Indiana, Kansas, Maine, Maryland, Massachusetts, Michigan, Missouri, New Hampshire, New Jersey, New York, South Carolina, Texas, Utah, Washington, and Wisconsin. See Appendix 1 for further information.

65 ARIZ. AdmIN. CODE \14-5-202(R) (2015).

${ }^{66}$ Id. $\int 14-5-207(\mathrm{O})(1)$.

67 65-407-420 ME. CODE R. \6(C)(2)(s) (2015).

68 WASH. ADMIN. CODE \ 480-93-188(3) (2015).

${ }^{69}$ Id. \ 480-93-188(3)(d) (2015).

70 FLA. Admin. CODE r.25-12-040(1) (2015).

71 Kan. Admin. Regs. \ 82-11-4(dd) (2015).

72 MD. Code REgs. 20.55.09.05(B) (2015).

73 Mo. Code REgs. ANN. tit. 4, \ 240-40.030(13)(M) (2015). 


\section{- Endnotes Continued -}

74 Significant property damage refers to damage valued at $\$ 50,000$ or more, including the cost of leaked gas. See Pipeline and Hazardous Materials Safety Administration, Significant Incident 20 Year Trend: Gas Transmission, SIGNIFICANT INCIDENTS, https:// hip.phmsa.dot.gov/analyticsSOAP/saw.dll?Portalpages (last visited Sep. 18, 2015).

75 See Pipeline and Hazardous Materials Safety Administration, Significant Incident 20 Year Trend: Gas Distribution, SIGNIFICANT INCIDENTS, https://hip.phmsa.dot.gov/analyticsSOAP/saw.dll?Portalpages (last visited Sep. 18, 2015).

7649 C.F.R. $\int 192.703(c)(2015)$.

77 Shana Cleveland, Conservation Law Foundation, Into Thin Air: How Leaking Natural Gas INFRASTRUCTURE IS HARMING OUR ENVIRONMENT AND WASTING A VALUABLE RESOURCE 14 (2012), available at http://www.clf.org/static/natural-gas-leaks/WhitePaper Final lowres.pdf.

78 Id. at 15.

79 U.S. Department of Transportation Research and Special Programs Administration OfFice of Pipeline Safety, Guidance Manual for Operators of SMall Natural Gas Systems, IV-14 - IV17 (2002), available at http://phmsa.dot.gov/portal/site/PHMSA/menuitem.6f23687cf7b00b0f22e4c6962d9c8 789/?vgnextoid =a7c6ca170a574110VgnVCM1000009ed07898RCRD\&vgnextchannel $=67027 \mathrm{e} 2 \mathrm{~cd} 44 \mathrm{~d} 3110 \mathrm{Vgn}$ VCM1000009ed07898RCRD\&vgnextfmt=print.

80 The states are Arizona, Arkansas, Connecticut, Florida, Georgia, Kansas, Kentucky, Maine, Massachusetts, New Hampshire, New Mexico, North Carolina, Ohio, South Carolina, Tennessee, Texas, and Washington. We note that the regulations in Arizona and North Carolina require pipeline operators to classify leaks in accordance with ASME Guide for Gas Piping Systems. See Appendix 2 for further information.

81 The two states are Missouri and New York. See Appendix 2 for further information.

${ }^{82}$ Lamb et al., supra note 10, at 5162 (noting that "[b]ecause leaks are classified on the basis of safety (i.e., proximity to buildings) and not magnitude, class 1 leaks are not necessarily larger than class 2 or 3 leaks").

83 See, for example, GA. COMP. R. \& REgS. 515-9-1-.05, Exhibit A (2015); KAN. Admin. REgS. \ 82-11-4(bb) (2015); 65-407-420 ME. CODE R. \6(D)(2)(a) (2015).

8449 C.F.R. S 192.703(c) (2015). 


\section{- Endnotes Continued -}

85 The fifteen states are Arizona, Arkansas, Florida, Georgia, Kansas, Maine, Massachusetts, Michigan, Missouri, New Hampshire, New York, Ohio, Tennessee, Texas, and Washington. It should be noted that, in Arizona, mandatory timeframes have been established for the repair of underground leaks from transmission pipelines only. For further information, see Appendix 2.

86 U.S. Energy Information Administration, Natural Gas Other Disposition Items, NATURAL GAS ANNUAL

RESPONDENT QUERY SYSTEM (EIA-176 DATA THROUGH 2013), http://www.eia.gov/cfapps/ngqs/ngqs.cfm?

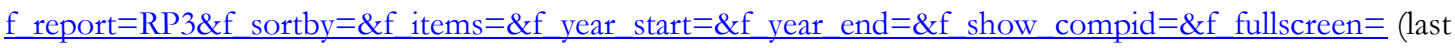
visited Jun. 12, 2015) (indicating that, in 2013, 197,938,142 thousand cubic feet of gas was lost through leaks, while the total disposition volume was $138,879,490,748$ thousand cubic feet).

${ }^{87} I d$.

${ }^{88} I d$.

${ }^{89}$ FLA. ADMIN. CODE ANN. r. 25-12.040(2)(b) (2015).

90 Mo. Code REGs. ANN. tit. 4, \240-40.030(14)(C)(2) (2015).

91 The nine states are Georgia, Kansas, Michigan, New Hampshire, New York, Ohio, Tennessee, Texas, and Washington. It should be noted that, in Arizona, pipeline operators are given up to one year to repair certain Grade 2 leaks (on underground transmission pipelines). See Appendix 2 for further information.

92 The five states are Georgia, Michigan, New York, Ohio, and Tennessee. It should be noted that, in Arizona, pipeline operators are given up to one year to repair certain Grade 2 leaks (on underground transmission pipelines). See Appendix 2 for further information.

93 ARIZ. AdMIN. CODE \14-5-202(R) (2015).

94 Fla. Admin. CODE ANN. r. 25-12.040(2)(c) (2015).

95 KAN. Admin. REGS. \ 82-11-4(bb) (2015).

96 65-407-420 ME. CODE R. \6(d)(4)(c) (2015).

97 Mo. Code Regs. ANN. tit. 4, \ 240-40.030(14)(C)(3) (2015).

9816 TEX. ADMIN. CODE \ 8.207(d) (2015).

99 Cleveland, supra note 77, at 16. 


\section{- Endnotes Continued -}

100 65-407-420 ME. CODE R. \6(D)(8) (2015).

101 OHio Admin. Code 4901:1-16-04(I)(1) (2015).

$102 I d$.

10349 CFR \ 191.23(a)(6) (2015).

104 Pipeline and Hazardous Materials Safety Administration, Incident Reporting, http://www.phmsa.dot.gov/incident-report (last visited May 21, 2015).

10549 CFR \ 191.23(b)(3) (2014).

106 See Pipeline and HaZardous Materials SAFEty Administration, Form PHMSA 7100.1-1 (ANNUAL REPORT FOR GAS DISTRIBUTION SYSTEM), available at http://phmsa.dot.gov/staticfiles/PHMSA/Download ableFiles/Files/Pipeline/HL $\% 20$ Annual $\% 20$ Report $\% 20$ Form $\% 20-\% 20$ PHMSA $\% 20$ F\%2070001.1\%20(rev\%206-2014).pdf; PiPELINE AND HAZARDOUS MATERIALS SAFETY ADMINISTRATION, FORM PHMSA 7100.2-1 (ANNUAL REPORT FOR GAS TRANSMISSION AND GATHERING PIPELINE SYSTEMS), available at http://phmsa.dot.gov/staticfiles/PHMSA/DownloadableFiles/Files/Forms/GT\%20GG\%20Annual

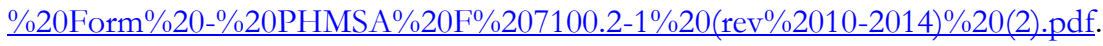

107 See Pipeline and Hazardous Materials Safety Administration, Data \& Statistics, http://www.phmsa.dot.gov/pipeline/library/data-stats (last visited Jul. 22, 2015).

108 The eight states are Arkansas, Connecticut, Iowa, Maine, Massachusetts, New Hampshire, New Jersey, and Texas. In an additional twenty-three states, pipeline operators must file a copy of the annual report filed with the PHMSA with state regulators. These twenty-three states are Alabama, Arizona, California, Colorado, Florida, Illinois, Indiana, Kentucky, Louisiana, Maryland, Michigan, Mississippi, Nebraska, Nevada, New Mexico, New York, North Carolina, Ohio, Oklahoma, South Carolina, Utah, Washington, and Wisconsin. See Appendix 3 for further information.

109 65-407-420 ME. CODE R. \ 6G (2015); N.H. CODE ADMIN. R. ANN. PUC 509.15 (2015).

11016 Tex. Admin. Code \ 8.210(b) (2015).

11140 C.F.R. \ 98.232(e), (i) (2015).

112 It should, however, be noted that pipeline operators are required to directly measure methane emissions from metering and regulating facilities.

62 | Safety First, Environment Last | September 2015 


\section{- Endnotes Continued -}

11340 C.F.R. \ 98.233(q) (2015). See also U.S. ENVIRONMENTAL ProteCtiOn AgENCy, GrEENHOUSE GAS EMISSIONS REPORTING FROM THE PETROLEUM AND NATURAL GAS INDUSTRY: BACKGROUND TECHNICAL SUPPORT DOCUMENT 7 \& 47 (2009), available at http://www.epa.gov/ghgreporting/documents/pdf/2010/Subpart-W TSD.pdf.

114 The EFs were calculated using published data on methane leakage rates from 1992. See LISA M. CAMPBELL ET AL., METHANE EMISSIONS From THE NATURAL GAS Industry, VOLUME 9: UNDERGROUND PIPELINES, 36 - 40 (1996), available at http://www.epa.gov/gasstar/documents/emissions report/9 underground.pdf.

115 Id. at 36. See also U.S. ENVIRONMENTAL PROTECTION AGENCY, supra note 113, at 117 - 118.

116 Lamb et al., supra note 10, at c.

117 Zimmerle et al., supra note 10, at I.

118 Jonathan Peress, Environmental Defense Fund, Study Shows Utilities and Regulators Making Progress on Methane Leaks, But a Major Emissions Problem Remains, ENERGY EXCHANGE (Mar. 31, 2015), http://blogs.edf.org/energy exchange/2015/03/31/study-shows-utilities-and-regulators-making-progress-on-methane-leaks-but-a-majoremissions-problem-remains/.

119 U.S. DePARTMENT OF Transportation, supra note 51, at V-1. See also Bipartisan Policy CENTER, supra note 51 , at 8 .

120 Bipartisan Policy CENTER, supra note 51, at 8.

121 The table only lists state rules governing the detection of leaks on transmission and distribution pipelines. It does not cover leak detection on customer-owned service lines or meters.

122 The term "master meter system" refers to facilities for distributing gas within a definable area where the operator purchases metered gas from a provider to provide gas service to two or more buildings other than at a single family residence. See ARIZ. ADMIN. CODE \ 14-5-201(15) (2015).

123 ARIZ. AdmIN. CODE SS 14-5-202(Q)-(R), 14-5-207(O) (2015).

124 126-01-001 ARK. CODE R. \192.723(b), (c) (2015).

125 California Public Utilities Commission, General Order No. 112-E: State of California Rules Governing Design, Construction, Testing, Operation, And MAintenanCE of Gas Gathering, TRANSMISSION, AND DISTRIBUTION PIPING SYSTEMS (2008), available at http://docs.cpuc.ca.gov/ PUBLISHED/GENERAL ORDER/126869.htm (hereinafter CPUC General Order No. 112-E).

63 | Safety First, Environment Last | September 2015 


\section{- Endnotes Continued -}

126 Conn. Agencies Regs. IS 16-11-12(a), (d) (2015).

${ }^{127}$ D.C. Mun. Regs. tit. 15, \2305.1 (2015).

128 FLA. ADMIN. CODE r.25-12.040(1) (2015).

129170 Ind. ADMIN. CODE 5-3-2(12).

130 KAn. Admin. Regs. \82-11-4(cc)-(dd) (2015).

131 65-407-420 ME. Code R. \6(C) (LexisNexis 2015).

132 MD. Code ReGs. 20.55.09.05 (2015).

133220 MASS. CODE REGS. 101.06(21) (2015).

${ }^{134}$ Mich. AdMin. CODE r. 460.20102(f), 460.20312, 460.20325 (2015).

135 Mo. Code Regs. ANN. tit. 4, \240-40.030(13)(D), (M) (2015).

136 A "business district" is defined as the principal business areas in the urban portion of a community. See N.H. Code Admin. R. ANN. PUC 508.04(a) (2015).

137 N.H. Code Admin. R. ANN. PUC 508.04(d), (f), (g)-(h) (2015).

138 N.J. AdmIN. CODE SS 14:6-2.3, 14:6-2.6, 14:7-1.20 (2015).

139 N.M. CODE R. \18.60.2.8(B)(3) (2015).

140 N.Y. Comp. Codes R. \& Regs. tit. 16, \\255.3(11)-(12), 255.705, 255.706, 255.721, 255.723, 255.809 (2015).

141 OHIO Admin. CODE 4901:1-16-04(H) (2015).

142 S.C. Code ANn. Regs. 103-493(3)-(4), 103-465(1)(b) (2015).

14316 Tex. ADMIN. CODE \8.206(b), (c), (e), (g) (2015).

144 Utah Admin. Code r. 746-409-7(B) (2015).

145 Wash. Admin. CODE \480-93-188 (2015).

146 WIs. ADMIN. CODE PSC $₫ 135-723$ (2015). 


\section{- Endnotes Continued -}

147 The table does not list requirements relating to the maintenance of records of leakage surveys conducted by pipeline operators.

148 ARIZ. Admin. CODE \14-5-202(Q)(1), (R) (2015).

149 126-01-001 ARK. CODE R. \192.723(d), (e), (h) (2015).

15026 Del. Admin. CodE \ 8001 (2015).

151 Fla. Admin. CODE ANN. r. 25-12.040(2) (2015).

152 GA. COMP. R. \& REGS. 515-9-1-.05 (2015).

153170 Ind. AdMIN. CODE 5-3-2(1), (12) (2015).

154 KAN. Admin. REGS. \ 82-11-4(y), (bb) (2015).

155807 Ky. Admin. REgS. 5:022 (2015).

156 LA. AdMIN. CODE tit. 43, 』 2911 (2015).

157 65-407-420 ME. CODE R. \ 6(D) (2015).

158 MASS. GEN. LAWS ch. 164, 』144(b), (d) (2015).

159 Mich. Admin. CoDE r. 460-20327 (2015).

160 Mo. Code REgs. ANN. tit. 4, \ 240-40.030(13)(B), (14)(C) (2015).

161 N.H. Code Admin. R. ANN. PUC 508.04(m), (q) (2015). The New Hampshire Public Utilities Commission may impose additional restrictions on the downgrading of leaks. See, for example, New Hampshire Public Utilities Commission, Settlement Agreement DG 11-040 April 9, 2012 Attachment J, SAFETY RuLES, http://www.puc.nh.gov/Safety/Rules/Safety\%20Rules.htm\# Toc374618896 (last visited Jun. 12, 2015) (indicating that EnergyNorth must not downgrade any leaks).

${ }^{162} I d$. (requiring EnergyNorth to ensure that there are no more than 1,125 Grade 3 leaks on its distribution system at the end of December 2012, reduce the number of Grade 3 leaks at a 3-year rolling average of 70 Grade 3 leaks per year, and reduce the number of outstanding Grade 3 leaks to no more than 425 by 2022).

163 N.J Admin. CODE \14:6-2.3(a) (2015).

164 N.M. CODE R. \18.60.2.11, 18.60.2.12 (2015). 


\section{- Endnotes Continued -}

165 Type 2 leaks where a reading above 1 percent, but below 4 percent gas-in-air is detected within manholes, vaults, or catch basins must be repaired within 6 months and reevaluated every 2 weeks until repaired. N.Y. COMP. CODE R. \& Regs. tit 16, $\$ 255.815$ (b)-(c) (2015).

166 N.Y. COMP. CODE R. \& REGS. tit 16, \\ 255.805(c), (g)-(h), 255.811(a) -(d), 255.813(a)-(c), 255.815(a), 255.817(a) (2015).

1674 N.C. ADMIN. CODE 6-21(1) (2015).

168 OHIO Admin. CODE 4091:1-16-04(H), (I) (2015).

169 S.C. CODE ANN. REgs. 103-493 (2015).

170 TENN. COMP. R. \& REgS. \1220-4-5-.44(5) (2015).

171 16 TEX. Admin. CODE $\int 8.207$ (2015).

172 WASH. ADMIN. CODE SS 480-93-186(1), (4), 480-93-18601(2)-(3) (2015).

173 Alabama Public Service Commission, Revisions to the Commission's Gas Pipeline Safety Rules, Order Approving STAFF's Proposed RulEs ReVISIONS: DOCKET 17546 (2004), available at http://www.psc.state.al.us/Administrative/gpsrules.pdf.

174 ARIZ. AdMIN. CODE $\iint 14-5-203(C)(1), 14-5-204($ A) (2015).

175 126-01-001 ARK. CODE R. SS 191.5(d), 191.11(a), 191.17(a), 191.27 (2015).

176 CPUC General Order 112-E, IS 122.1, 122.2, 122.3.

177 COLO. Code Regs. \$\$ 723-4912(a), 723-4913(a) (2015).

178 ConN. Agencies Regs. IS 16-11-12(c), 16-16-2, 16-16-3 (2015).

${ }^{179}$ D.C. Mun. Regs. tit. 15, SS 2306.1, 2306.3(a)(2), 2306.7 (2015).

180 Fla. Admin. CODE ANN. r. 25-12.084, 25-12.085(1), (3) (2015).

181 GA. COMP. R. \& REGS. 515-9-1-.06 (2015).

182 IDAHO ADMIN. CODE r. 31.11.01.302 (2015). See also IDAHO ADMIN. CODE r. 31.11.01.302 (2015).

183 ILL. ADMIN. CODE tit. 83, \590.20 (2015). 


\section{- Endnotes Continued -}

184170 IND. ADMIN. CODE 5-3-4 (b)-(c), (e) (2015).

185 IOWA ADMIN. CODE r. 199-10.17, 199-19.2(d), (g), 199-19.17(1) (2015).

186 KAN. ADMIN. REGS. \ 82-11-3 (2015).

187807 KY. ADMIN. REGS. 5:027, \S 3, 5, 7, 8 (2015).

188 LA. Admin. Code tit. 43, Pt. XIII, JS 309(A), 311, 3015(A) 317 (2015). See also LA. Admin. CodE tit. 43, Pt. XIII, \S 303, 305 (2015).

189 65-407-420 ME. CODE R. SS 4B, 6F, 6G; 65-407-130 ME. CODE R. SS 2(1), 3(1), (2) (2015).

190 MD. Code REGS. 20.55.03.02(H)-(I) (2015).

191 MASs. GEN. LAws Ch. 164, SS 1I, 144(e) (2015); 220 MASS. CODE REgS. 79.01 (2015).

192 MiCH. AdMIN. CODE r. 460.20503, 460.20504 (2015).

193 Minnesota Department of Public SAFETy, MNOPS REPORTABle EVENT Policy (2015), available at https://dps.mn.gov/divisions/ops/forms-documents/Documents/MNOPS $\% 20$ Reportable $\% 20$ Events $\% 20$ Policy.pdf; Minnesota Department of Public SAFety, Alert Notice - MNOPS AL - 04-2010 TO Natural Gas Pipeline Operators - RePorting of Gas Pipeline LEAKs CAused by ExCAVATION (2011), available at https://dps.mn.gov/divisions/ops/forms-documents/Documents/Alert\%2020104\%20Rev $\% 208$.pdf.

194 Mo. Code Regs. Ann. tit. 4, J 240-40.020 (2015).

195155 NEB. ADMIN. CODE SS 002.01, 003 (2015).

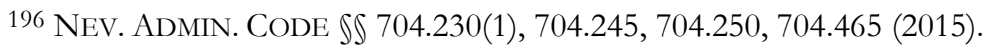

197 N.H. CodE Admin. R. ANN. PUC 504.05(a), 504.06(a), 508.03(b), 509.15 (2015).

198 N.J. Admin. CODE SS 14:3-6.4, 14:3-6.5, 14:3-6.6, 14:7-1.20(f), 14:7-1.26(c)-(d) (2015).

199 N.M. CODE R. SS 18.60.2.8(A)-(B), 80.60.3.8(A)-(B) (2015).

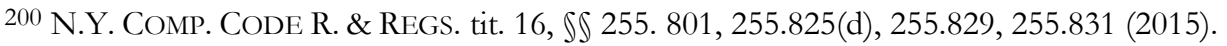

2014 N.C. ADMIN. CODE 6-41 (2015). 


\section{- Endnotes Continued -}

202 OHio Admin. Code 4901:1-16-05(A)-(B) (2015).

203 OKLA. ADMIN. CODE SS 165:20-5-1, 165:20-5-11, 165:20-5-13(a)-(b), 165:20-5-14(a)-(b), 165:20-5-15, 165:20-5-16 (2015).

204 OR. Admin. R. 860-024-0050(2) (2015). See also OR. ADMIN. R. 860-024-0050(1) (defining “serious injury to property" to include damage to the property of a gas operator exceeding $\$ 5,000$ ).

20559 PA. CODE \ 59.11 (2015).

206 STATE of RHODE ISLAND Division OF PUBLIC UTILITIES AND CARRIERS, RHODE ISLAND RULES AND REgulations PREscribing STANDARDS FOR GAs UtiLities APPENDix B (2006), available at http://www.ripuc.org/rulesregs/divrules/Gas\%20Rules\%20 D-06-15 \%20$\% 20$ Corrected $\% 20$ Rules $\% 20$ Appendix $\% 202$.pdf.

207 S.C. CODE ANN. REGS. 103-412(2.6), 103-415(A) (2015).

208 TENN. COMP. R. \& REGS. SS 1220-4-5-.06(1)(f), 1220-4-5-.36(1)(c) (2015).

20916 Tex. Admin. CodE \8.210 (2015).

210 UTAH AdMIN. CODE r. 746-409-4(A)-(D) (2015).

211 30-47 VT. CODE R. \6.160.

212 WASH. ADMIN. CODE \480-93-200(1), (2), (4) (10)(a) (2015).

213 W. VA. CODE R. 』 150-4-9.6 (2015).

214 Wis. AdMIN. CODE PSC 135.016 (2015).

215 023-IV WyO. CODE R. \420(a)-(b) (2015). See also 023-II WyO. CODE R. \ 232 (2015). 


\section{KBH Center for Energy, Law, and Business}

\section{EXECUTIVE COUNCIL}

Duke R. Ligon, Co-chair

Sam L. Susser, Co-chair

Linda L. Addison

James H. Clement, Jr.

Joseph C. Dilg

Dan O. Dinges

The Honorable Kay Bailey Hutchison

Rob L. Jones

Sylvia J. Kerrigan

James Lloyd Loftis

W. Matt Ralls

Rad Weaver

\section{ADVISORY COUNCIL}

Matthew Acock

Juan M. Alcalá

S. Jack Balagia, Jr.

Karl Bayer

David J. Beck

Laura H. Beckworth

Jeff Civins

Lyn Clancy

John B. Connally, IV

James E. Cousar

Richard D. Deutsch

Harry Gee, Jr.

Pamela M. Giblin

R. Kinnan Golemon

Rene Gonzalez

Stephanie C. Hildebrandt

Monty Humble

The Honorable James R. Jones

The Honorable Robert W. Jordan

The Honorable Rebecca A. Klein

David B. Kultgen

Diana Liebmann
The Honorable Tom G. Loeffler

Joel H. Mack

W. James McAnelly, III

Michael A. McConnell

James C. Morriss, III

Suzanne Murray

Larry W. Nettles

Jon P. Newton

Ashley T.K. Phillips

James M. Rhodes

The Honorable Arturo Sarukhán

Jennifer M. Smith

The Honorable Barry T. Smitherman

James M. Spellings, Jr.

Marcello E. Tamez

Timothy J. Tyler

D. Marie Wagner

Robert C. Walters

Dick Watt

Roderick E. Wetsel

John F. Wombwell

Libin Zhang 